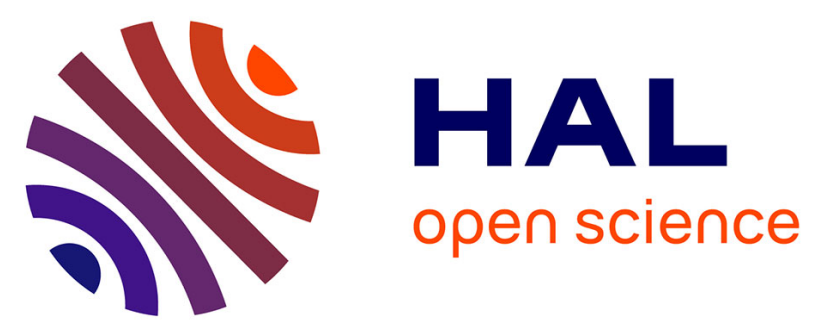

\title{
Last Glacial aeolian landforms and deposits in the Rhône Valley (SE France): Spatial distribution and grain-size characterization
}

Mathieu Bosq, Pascal Bertran, Jean-Philippe Degeai, Sebastian Kreutzer, Alain Queffelec, Olivier Moine, Eymeric Morin

\section{To cite this version:}

Mathieu Bosq, Pascal Bertran, Jean-Philippe Degeai, Sebastian Kreutzer, Alain Queffelec, et al.. Last Glacial aeolian landforms and deposits in the Rhône Valley (SE France): Spatial distribution and grainsize characterization. Geomorphology, 2018, 318, pp.250 - 269. 10.1016/j.geomorph.2018.06.010 . hal-01844757

\section{HAL Id: hal-01844757 \\ https://hal.science/hal-01844757}

Submitted on 16 Jun 2020

HAL is a multi-disciplinary open access archive for the deposit and dissemination of scientific research documents, whether they are published or not. The documents may come from teaching and research institutions in France or abroad, or from public or private research centers.
L'archive ouverte pluridisciplinaire HAL, est destinée au dépôt et à la diffusion de documents scientifiques de niveau recherche, publiés ou non, émanant des établissements d'enseignement et de recherche français ou étrangers, des laboratoires publics ou privés. 


\title{
Last Glacial aeolian landforms and deposits in the Rhône Valley (SE France): Spatial distribution and grain-size characterization
}

Mathieu Bosq ${ }^{a}$, Pascal Bertran ${ }^{a, b}$, Jean-Philippe Degeai ${ }^{c}$, Sebastian Kreutzer ${ }^{d}$, Alain Queffelec ${ }^{a}$, Olivier Moine ${ }^{e}$, Eymeric Morin ${ }^{\mathrm{f} g}$

\author{
a PACEA, UMR 5199 CNRS - Université Bordeaux, Bâtiment B8, allée Geoffroy Saint Hilaire, 33615 Pessac, France \\ ${ }^{\mathrm{b}}$ Inrap, 140 avenue du Maréchal Leclerc, 33130 Bègles, France \\ c ASM, UMR 5140 CNRS - Université de Montpellier III, route de Mende, 34199 Montpellier, France \\ d IRAMAT-CRP2A, UMR 5060 CNRS - Université Bordeaux Montaigne, Maison de l'Archéologie, 33607 Pessac, France \\ e LGP, UMR CNRS 8591, Université Paris I Panthéon-Sorbonne/Université Paris-Est-Créteil-Va1-de-Marne (UPEC), place \\ Aristide Briand, 92195 Meudon, France \\ ${ }^{\mathrm{f}}$ Inrap, 6 rue Jean Bertin, 26901 Valence, France \\ g EVS, UMR CNRS 5600, Université Lumière - Lyon II, 86 rue Pasteur, 69007 Lyon, France
}

\section{Abstract}

In the Rhône Valley, a north-south oriented Cenozoic rift in southeast France, thick Pleistocene loess deposits have been recognized since the beginning of the last century. These loess records, which are disconnected from the North European Loess Belt (NELB), are of significant interest to document the evolution of perimediterranean landscapes and environments during the Last Glacial. To overcome the poor precision of available aeolian distribution maps, aeolian deposits were mapped using the topsoil textural database provided by the Land Use and Cover Area frame Statistical Survey project (LUCAS). The grain-size distribution of aeolian sand and loess was first determined using 116 samples taken from surveyed outcrops. Then, the areas showing a similar grain-size composition were extracted from the LUCAS rasters. The resulting map reproduces the conventional maps correctly but suggests a more significant extension of loess, in better agreement with the known distribution of outcrops. The map shows that the distinctive morphology of the valley dominantly controls the distribution of aeolian deposits. The deflation-related landforms, i.e., yardangs, closed depressions (pans), and desert pavements, are widespread south of narrowings of the Rhône Valley between latitudes $44^{\circ} \mathrm{N}$ and $45^{\circ} \mathrm{N}$. They indicate palaeowinds blowing from the north/northwest. Aeolian sand, loessic sand, sandy loess, and loess deposits successively spread on both sides of the Rhône River. The loess is characterized by a coarse texture (main mode around $60 \mu \mathrm{m}$ ), strong local thickness (N5 m), limited extension, and abundant bioturbation. This preservation results from the persistence of a shrub vegetal cover during the coldest and driest phases of the Last Glacial that allowed for trapping the saltating and suspended particles close to the alluvial sources.

Keywords: Aeolian deposits ; Cartography ; Grain-size distribution ; Last Glacial ; LUCAS topsoil database ; Yardangs 


\section{Introduction}

During the last glacial period, glacier advance, sea-level drop, climate aridification, and decrease in vegetal cover favoured aeolian dynamics and led to the deposition of widespread coversand and loess in Europe. Over the last few decades, much attention was paid to the aeolian deposits of northern Europe and the Atlantic coast to reconstruct the millennial environmental variability of the Last Glacial (e.g., Kasse, 1997; Vandenberghe et al., 1998; Antoine et al., 2009, 2013, 2016; Meszner et al., 2013; Újvári et al., 2014; Sitzia et al., 2015; Costas et al., 2016; Haesaerts et al., 2016; Lehmkuhl et al., 2016; Sauer et al., 2016; Zens et al., in press).

At the same time, mapping aeolian deposits at regional to European scales was the subject of significant improvements based on either conventional geological approaches or the use of soil databases (Zeeberg, 1998; Haase et al., 2007; Bertran et al., 2016; Lindner et al., 2017). This allowed for better understanding of the relationships between the mapped units as part of aeolian systems and of their potential sources. Palaeowind reconstruction from field evidence also provided valuable data to compare with the simulations of Last Glacial Maximum (LGM) atmospheric circulation in Europe provided by global climate models (GCMs) (Renssen et al., 2007; Sima et al., 2013; Hopcroft et al., 2015). Mapping of aeolian deposits also allowed the identification of previously underestimated factors that influenced prehistoric settlement in Europe. For example, sandy deserts were unfavourable areas for Palaeolithic settlement because of the low plant and animal biomass and reduced water availability. They thus acted as palaeogeographic barriers and contributed to the isolation of European peopling areas during the phases of maximum coversand extension (Bertran et al., 2013). Similarly, during the Holocene, soil productivity on loess favoured the spreading of agriculture in Europe, and the loessic lands served as a corridor for Neolithic colonisation (Schlummer et al., 2014).

Overall, aeolian deposits cover relatively restricted (although probably largely underestimated) areas in Mediterranean regions in comparison with the North European Loess Belt (NELB). Most of our knowledge of perimediterranean loess come from recent studies in Spain (Boixadera et al., 2015; Calvo et al., 2016) and Israel (Crouvi et al., 2008). In France, thick loess sequences were also described in the Rhône Valley since the 1930s (Suen, 1934; Bonifay, 1962, 1965) but were the focus of only limited investigations so far. Because of its key location between north European periglacial areas and more temperate Mediterranean regions during the LGM, the Rhône Valley provides a unique opportunity to investigate the glacial palaeoenvironments at the transition between these two domains.

The aim of this article is to better document the aeolian system of the Rhône Valley through (i) mapping the deposits and associated landforms by coupling a field approach, the use of highresolution $(5 \mathrm{~m})$ digital elevation model (DEM) and soil databases, and (ii) analysing the grain-size distribution and its spatial evolution to identify the factors involved in particle transport and accumulation. We will then discuss the similarities and distinctiveness of the Rhône Valley in comparison with other aeolian systems in Europe.

\section{Regional setting}

\subsection{Geological and geomorphological setting}

The Rhône Valley is a N-S oriented continental rift belonging to the European Cenozoic Rift System (Dèzes et al., 2004; Ziegler and Dèzes, 2007). The graben is bounded to the west by the Massif 
Central that comprises mainly Palaeozoic metamorphic and plutonic rocks and to the east by pre-alpine ranges composed of Mesozoic and Cenozoic sedimentary rocks (Fig. 1). The northern part of the study area is the Bresse Graben drained by the Saône River. The graben infilling is Oligocene to Miocene. Miocene molasses supplied by erosion of the ranges form conglomerates, and sandstone plateaus are mainly located on the eastern side of the graben. These deposits may have acted as an important particle source for deflation during the Pleistocene. During the Messinian salinity crisis (5.9-5.32 Ma) (Hsü et al., 1973; Clauzon et al., 1996), the sea level drop of $\sim 1500 \mathrm{~m}$ caused a major incision of the Rhône canyon (Clauzon, 1982; Mocochain et al., 2006). Then, Pliocene transgression deposited thick marine clay series in the rias (Mocochain et al., 2009).

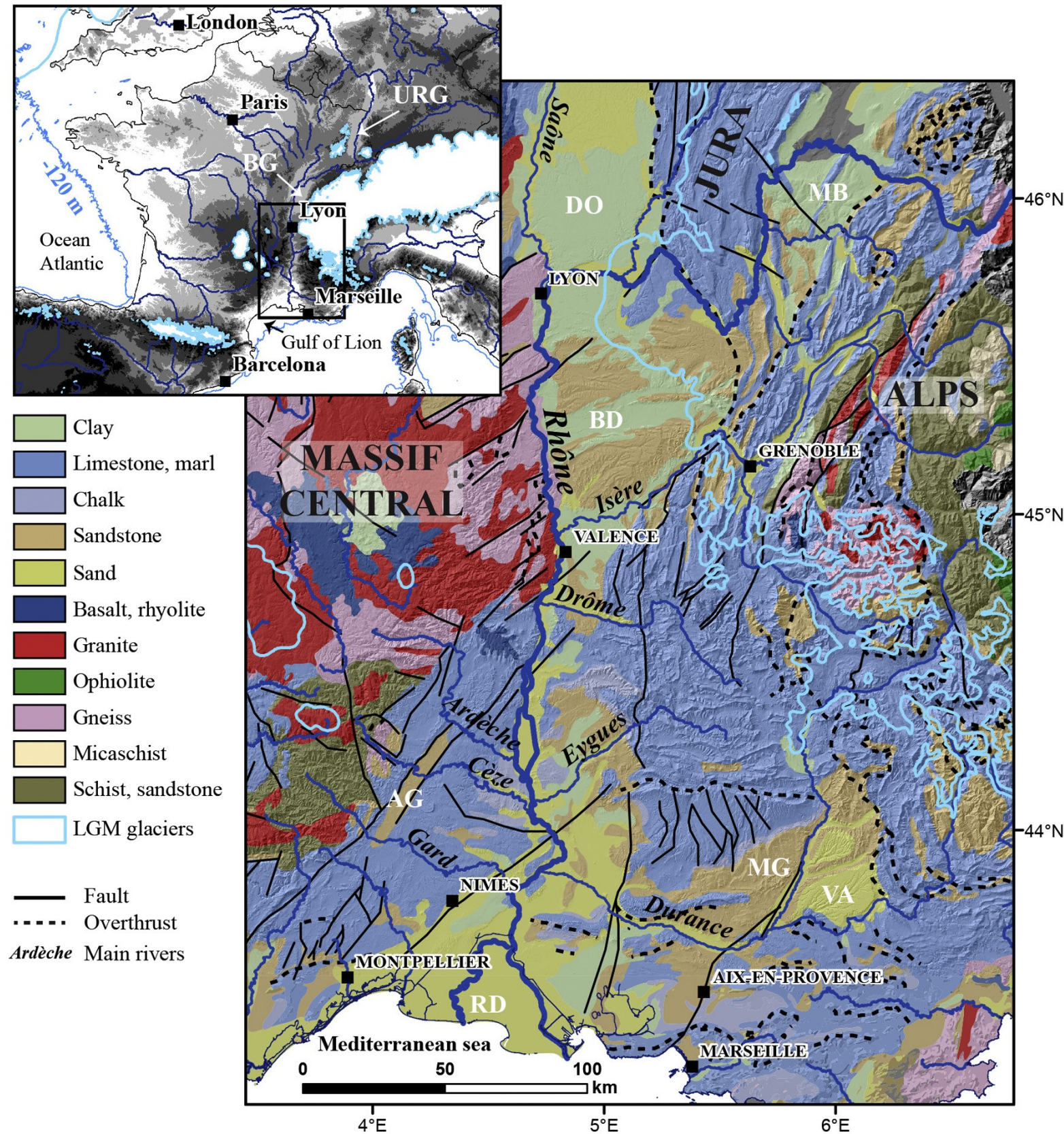

Fig. 1. Simplified 1:1,000,000 lithological map of southeast France (from BRGM, infoterre.brgm.fr). The white line indicates the extension of the alpine and Massif Central ice caps during the LGM (adapted from Ehlers and Gibbard, 2004). The main sedimentary basins are indicated by the following abbreviations: AG: Alès Graben, BD: Bas Dauphiné, BG: Bresse Graben, DO: Plateau des Dombes, MB: Molasse Basin, MG: Manosque Graben, RD: Rhône Delta, VA: Plateau de Valensole, URG: Upper Rhine Graben. 
The reconstruction of the alpine ice cap (Ehlers and Gibbard, 2004; Buoncristiani and Campy, 2011) indicates that the ice lobe supplied by the Isère River basin covered the Dombes plateau and crossed the Rhône River near Lyon during the middle Pleistocene. This lobe led to the formation of an ice-damned lake in the Bresse Graben (Mandier, 1984). During the Last Glacial, the extent of the alpine ice cap was more limited and did not exceed the eastern edge of the Rhône Valley (Fig. 1). The age of the Local Last Glacial Maximum (LLGM) is still under debate and may have been older than Marine Isotope Stage 2 (MIS 2) (Schoeneich, 1998; Jorda et al., 2000; Ivy-Ochs et al., 2008; Coutterand, 2010). Widespread outwash deposits derived from the alpine ice cap have also been potentially a major particle source of deflation.

The recognition of loess in southeastern France began with the work of Marcelin (1926) in the Nîmes area. Suen (1934) then proposed a first map of the loess in the Rhône Valley. He noted a significant change in colour and texture downstream from Valence where the loess becomes coarser and reddish. In the following decades, many studies revealed thick loess deposits (Tricart, 1952; Mazenot, 1956, 1957, 1965; Bourdier, 1961; Bonifay, 1962, 1965; Alimen, 1965; Dubar, 1972, 1979, 1983) as well as sand dunes, ventifacts, and (niveo-)aeolian pans (Gabert, 1965; Gabert-Delay, 1967; Ambert, 1973, 1974, 2013; Chardon, 1975; Clauzon et al., 1990; Ambert and Clauzon, 1992). Polygonal wedge networks caused by ground thermal contraction and filled with windblown sand (sand wedges) were also described (Bouteyre and Allemann, 1964; Gabert-Delay, 1967; Cailleux and Rousset, 1968; Nury and Roux, 1969; Arnal, 1971a, 1971b). Windblown sand also contributed to the infilling of karst cavities (Brochier and Livache, 1978; Debard, 1987, 1988; Lopez Saez and Texier, 1998; Texier et al., 2003; Saos et al., 2014; Puaud et al., 2015). The main conclusions that can be drawn from these works are as follows:

- The loess thickness reaches locally N10 m (Bonifay, 1962, 1965).

- Loess is coarse and has a high carbonate content (Alimen, 1965; Dubar, 1979).

- A gradient occurs in the composition of the loess malacofauna along the Rhône corridor, suggesting a transition between periglacial milieus to the north and xerothermic environments near the Mediterranean Sea (Mazenot, 1956, 1957, 1965).

- Two main generations of loess separated by a thick red palaeosol assumed to be interglacial can be identified (old Rissian loess and recent Würmian loess) (Bonifay, 1962, 1965).

- Numerical dates are scarce; the few available radiocarbon and OSL ages suggest that loess accumulated during the Pleniglacial ( $\sim 0-15 \mathrm{ka})$.

\subsection{Climate setting}

The Rhône Valley is characterized by a mosaic of climate (Joly et al., 2010) ranging from a typical southern Mediterranean climate with warm summers $\left(T_{\max } \geq 22^{\circ} \mathrm{C}\right)$ and predominantly winter precipitation (mean annual precipitation (MAP) $\geq 500 \mathrm{~mm}$ ) to an altered oceanic climate in the northern part (mean annual temperature $(\mathrm{MAT})=12.5^{\circ} \mathrm{C}, \mathrm{MAP}=800-900 \mathrm{~mm}$ ) (Fig. A.1).

The wind regime is dominated by the Mistral, which blows from the north and exceeds $16 \mathrm{~m}$ $\mathrm{s}^{-1}$ for $\mathrm{N} 100 \mathrm{~d} / \mathrm{y}$ (Jacq et al., 2005). The air-mass movements triggered by the pressure difference between the Azores High over the North Atlantic and the Genoa depression in the Mediterranean area are channelled and accelerated by the Rhône corridor (Jiang et al., 2003). The mean wind intensity measured over the period 2000-2010 shows a gradual increase from the north to the south (Fig. 2). 
A

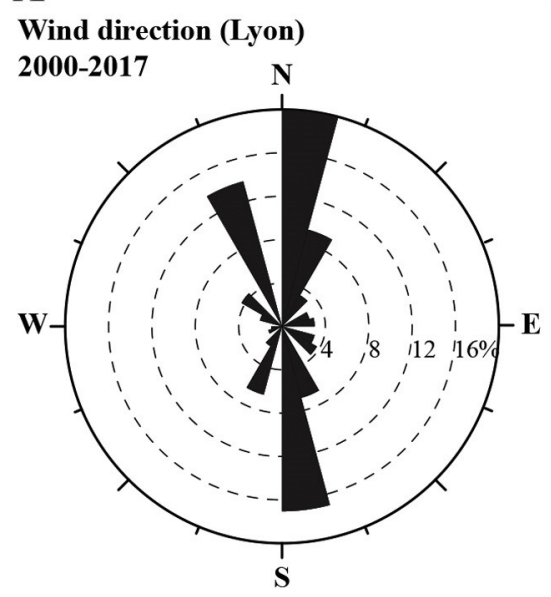

Wind direction (Marseille)

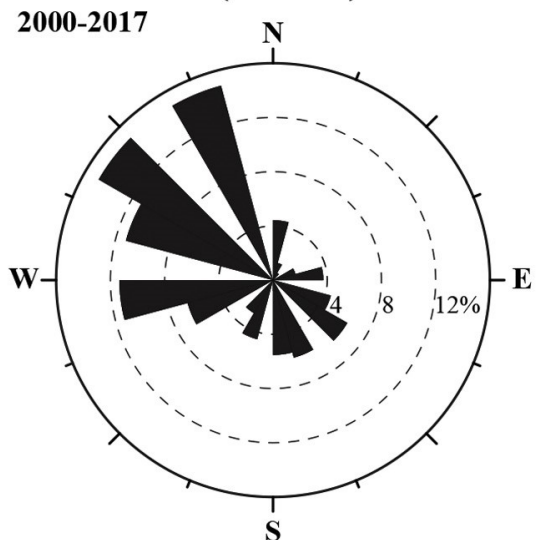

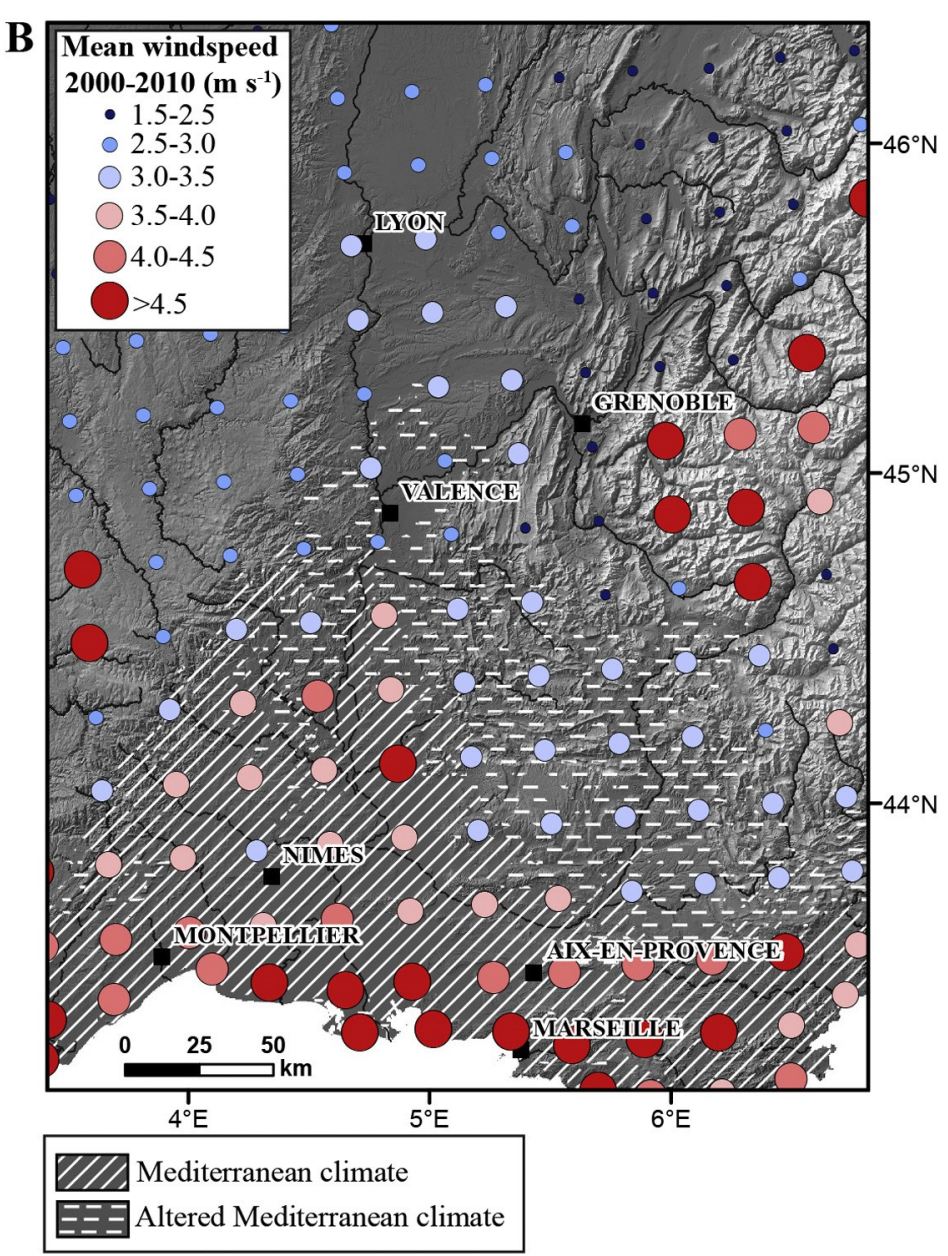

Fig. 2. (A) Rose diagrams of seasonal winds in the Rhône Valley (period 2000-2017) according to https://www.windfinder.com (Lyon-Bron and Marseille-Marignane meteorological stations); (B) digital elevation model (DEM) of the IGN and mean wind speeds $\left(\mathrm{m} \mathrm{s}^{-1}\right.$ ) at a height of $80 \mathrm{~m}$ from http://agri4cast.jrc.ec.europa.eu (accessed 2017).

The hatched and dashed areas indicate the geographical influence of the Mediterranean climate (after Joly et al., 2010, https://doi.org/10.4000/cybergeo.23155).

\section{Methodology}

\subsection{Field study}

The outcrops of aeolian deposits described in the literature (Table A.1) with a precise location have been georeferenced. Cross sections without description, drawings, or photographs were not taken into account. New field data were also collected in 2016 and 2017 as part of this study. The sections were manually cleaned and measured.

One or more representative samples were taken directly from the sections below the B horizon of the surface soil or with a hand auger at a depth of 0.8 to $1.2 \mathrm{~m}$ for grain-size analysis.

All the data were stored in a geographic information system on ArcGIS 10.5 (ESRI).

\subsection{Grain-size analysis}

The samples for grain-size analysis were processed at PACEA laboratory (Université de Bordeaux) using a Horiba LA-950 laser particle size analyser. After sieving with a $2 \mathrm{~mm}$ mesh to remove secondary carbonate concretions and roots, the sample pretreatment included suspension in sodium hexametaphosphate $(5 \mathrm{~g} / \mathrm{l})$ and hydrogen peroxide $(35 \%)$ at room temperature for $12 \mathrm{~h}$. As recommended by Schulte et al. (2016), the carbonates were not removed. Then, the suspension was 
subjected to $60 \mathrm{~s}$ ultrasonification to achieve optimal dispersion. The Mie solution to Maxwell's equation provided the basis for calculating the particle size (Jones, 2003; ISO, 2009), using a refractive index of 1.333 for water and $1.55 \mathrm{i}-0.01 \mathrm{i}$ for the particles. The grain-size distributions expressed in $\phi$ units were deconvoluted in different populations (parametric curve fitting method) using the R ( $R$ Core Team, 2018) package mixdist (Macdonald and Du, 2012) to identify the main modes. A log-normal distribution was used to fit the grain-size probability distribution of the samples as recommended by Qin et al. (2005). Several modes in loess deposits reflect either multiple sedimentary sources or different transport processes (Tsoar and Pye, 1987; Pye and Zhou, 1989; Pye, 1995; Weltje, 1997; Sun et al., 2002; Weltje and Prins, 2007; Stuut et al., 2009; Vandenberghe, 2013; Lin et al., 2016; Vandenberghe et al., 2018; Varga et al., in press). To compare the new laser diffraction grain-size data with those obtained by wet sieving of the particles $\mathrm{N} 50 \mu \mathrm{m}$ and by the pipette method for the particles b50 $\mu \mathrm{m}$, a calibration was performed on 20 loess samples using both methods. The sieve-pipette analysis was made at GEOPHEN laboratory (University of Caen-Normandie). As proposed by Makó et al. (2017), Lin's Concordance Correlation Coefficient (CCC) (Lin, 1989; Lin et al., 2002; Fisher et al., 2017) was calculated to compare the two data sets. The limits of grain-size classes for laser diffraction providing the highest CCC are as follows: b8 $\mu \mathrm{m}$ (clays), 8-56 $\mu \mathrm{m}$ (silts), N56 $\mu \mathrm{m}$ (sands) (Fig. A.2). These results are consistent with findings by other authors (e.g., Konert and Vandenberghe, 1997; Ramaswamy and Rao, 2006; Antoine et al., 2009, 2013) who showed that the amount of clay particles measured by laser diffraction is usually underestimated.

\subsection{Aeolian deposit mapping}

Various maps of the distribution of aeolian deposits in the Rhône Valley have been published. They were built (i) from conventional field mapping (Suen, 1934; 1:50,000 geological map from the Bureau de Recherches Géologiques et Minières (BRGM); European loess map: Haase et al., 2007) or (ii) using the topsoil $(0-20 \mathrm{~cm})$ textural database established by the European project Land Use and Cover Area from Statistical survey (LUCAS: Tóth et al., 2013; Bertran et al., 2016). Multiparameter interpolation of grain-size data from samples collected throughout Europe made it possible to generate maps in raster format for the topsoil content in clay, silt, sand, and coarse fragments expressed as percentages with a resolution of $500 \mathrm{~m}$ (Ballabio et al., 2016) (eusoils. jrc.ec.europa.eu). The distribution of aeolian deposits was then extracted by selecting each pixel corresponding to a composition of aeolian sand or loess (Bertran et al., 2016).

Both approaches have their own biases: (i) for conventional field mapping, the main difficulty lies in the identification of small loess areas and thin loess covers - bedrock rather than superficial formations is also predominantly shown in geological maps; (ii) for the maps derived from the LUCAS database, confusion is possible between loess and other deposits of similar texture; conversely, loess is not taken into account when its texture differs from the samples from northern France that were used as a reference to define the texture range of typical loess. Bertran et al. (2016) showed a good fit between the conventional loess map and that derived from the LUCAS database for northern Europe. By contrast, the loess extension in the Rhône Valley is greatly underestimated when compared to the data shown by the 1:50,000 geological map. According to Bertran et al. (2016), this problem could be mainly related to their coarse texture.

As part of this study, the approach proposed by Bertran et al. (2016) was followed. Nevertheless, to remedy the issues identified for the Rhône Valley, modifications were made. Table 1 illustrates the threshold values used to classify the aeolian deposits into four broad categories (loess, sandy loess, loessic sand, aeolian sand) based on 74 grain-size samples. The pixels corresponding to these categories were extracted from the LUCAS rasters (sand, silt, clay) using the (Raster Calculator) 
tool in ArcGIS. Then, the selected pixels were filtered by taking into account the proportion of coarse fragments (CF N $2 \mathrm{~mm}$ ). The upper CF limit was arbitrarily set at $22 \%$ between the mean ( $\mathrm{M}=19.4 \%$ ) and the mean plus one standard deviation $(M+\sigma=19.4 \%+6.7 \%)$. This high value compared to that used by Bertran et al. (2016) is justified by the large number of anthropogenic elements (ceramic and bricks fragments) in the topsoil caused by the high population densities typical of the region since the Neolithic period. Also, field studies showed that typical loess contains abundant carbonate concretions with a size $\mathrm{N} 2 \mathrm{~mm}$. However, the disadvantage of adopting such a high CF value as a limit is that it does not allow distinguishing primary and colluviated loess. The latter incorporate CF resulting from upslope bedrock erosion.

\begin{tabular}{lllll}
\hline Nature & Coarse fragments (\%) & Sand (\%) & Silt (\%) & Clay (\%) \\
\hline Loess & $x \leq 22$ & $x \geq 16$ & $x \geq 52$ & $x \leq 26$ \\
Sandy loess & $x \leq 22$ & $16 \geq x \leq 36$ & $34 \geq x \leq 52$ & $x \leq 26$ \\
Loessic sand & $x \leq 22$ & $x \geq 36$ & $x \geq 34$ & $x \leq 26$ \\
Aeolian sand & $x \leq 22$ & $x \geq 50$ & $x \leq 34$ & $x \leq 22$
\end{tabular}

Table 1. Grain-size limits used to map the sedimentary units.

Following this step, the created rasters were processed to eliminate isolated pixels and obtain more continuous map units. The ArcGIS tool (Block Statistics) was used for this treatment. It enables calculation of the average value for each pixel from the eight neighbouring pixels. Values below a $40 \%$ threshold were eliminated. The rasters for each category were then converted into polygons.

Several areas were removed from the resulting map: (i) mountainous lands above $550 \mathrm{~m}$ asl where the modelled texture is associated with significant uncertainty (Ballabio et al., 2016); (ii) the metamorphic and plutonic rocks of the Massif Central as delineated in the regolith map (Lacquement et al., 2010; Prognon et al., 2011), which are covered with sandy weathering deposits whose grain-size composition is sometimes close to that of sandy loess; (iii) the areas of Miocene molasse whose weathering materials may be confused locally with aeolian deposits; (iv) the Holocene sedimentary accumulations (mainly in valley) extracted from the 1:50,000 geological map (http://infoterre. brgm.fr/); and ( $\mathrm{v}$ ) the 30- to 40-cm-thick anthropogenic irrigation silts mentioned in the geological map in the Eyguières and Istres areas (L'Homer et al., 1975; Colomb et al., 1977).

\subsection{Spatial analysis}

ArcGIS was used to combine information on the distribution of aeolian deposits and on various parameters (altitude, slope orientation, slope gradient) derived from the digital elevation model (DEM) RGE $A_{L T I}{ }^{\otimes} 5 \mathrm{~m}$ from the Institut Géographique National (IGN) (http:// professionnels.ign.fr/), supplemented by the ALTI ${ }^{\otimes} 25 \mathrm{~m}$ (IGN) DEM in the areas where the first was not available. The distance of aeolian deposits from the main rivers (CARTHAGE ${ }^{\circledR}$ database, http:// professionnels.ign.fr/) was measured using ArcGIS tools. The deflation basins (pans) were delimited using the contour lines derived from the DEM $5 \mathrm{~m}$, and then the orientation of their elongation axis was measured on ArcGIS.

\subsection{Luminescence dating}

To provide a first chronological marker for the high-angle planar cross-bedded sands, two samples (BDX19710 and BDX19711) were taken for luminescence dating analysis at the Les Sablèyes quarry (see location in Figs. 3B and 6A). Onsite daylight sampling was carried out using opaque steel 
cylinders to extract ca. $450 \mathrm{~g}$ of sediment. The luminescence dating (luminescence measurements, dosimetry, data analysis) was carried out at the IRAMAT-CRP2A (Université Bordeaux Montaigne). The sample preparation followed conventional procedures (e.g., Preusser et al., 2008) for extracting the coarse grain (here: $125-160 \mu \mathrm{m}$ ) quartz fraction. The equivalent dose $\left(D_{e}\right)$ was determined by applying optically stimulated luminescence (OSL; Huntley et al., 1985) in conjunction with the single aliquot regenerative (SAR) dose protocol after Murray and Wintle (2000). Blue-OSL measurements were performed on a Freiberg Instruments lexsyg research reader (Richter et al., 2013) measuring multigrain aliquots. For the luminescence data analysis, we used the R package 'Luminescence' (Kreutzer et al., 2012; Kreutzer et al., 2018) and for the age calculation the software DRAC (Durcan et al., 2015). The dose-rate was calculated from $U, T h$, and $\mathrm{K}$ concentrations measured by high-resolution gamma-ray spectrometry at the IRAMAT-CRP2A. Full details on the luminescence dating are provided in Appendix B.

\section{Results}

\subsection{Aeolian landforms}

Field observations combined with DEM analysis revealed several aeolian landforms, located mainly south of the study area, in particular yardangs, endorheic depressions, and ventifact pavements (Fig. 3). 

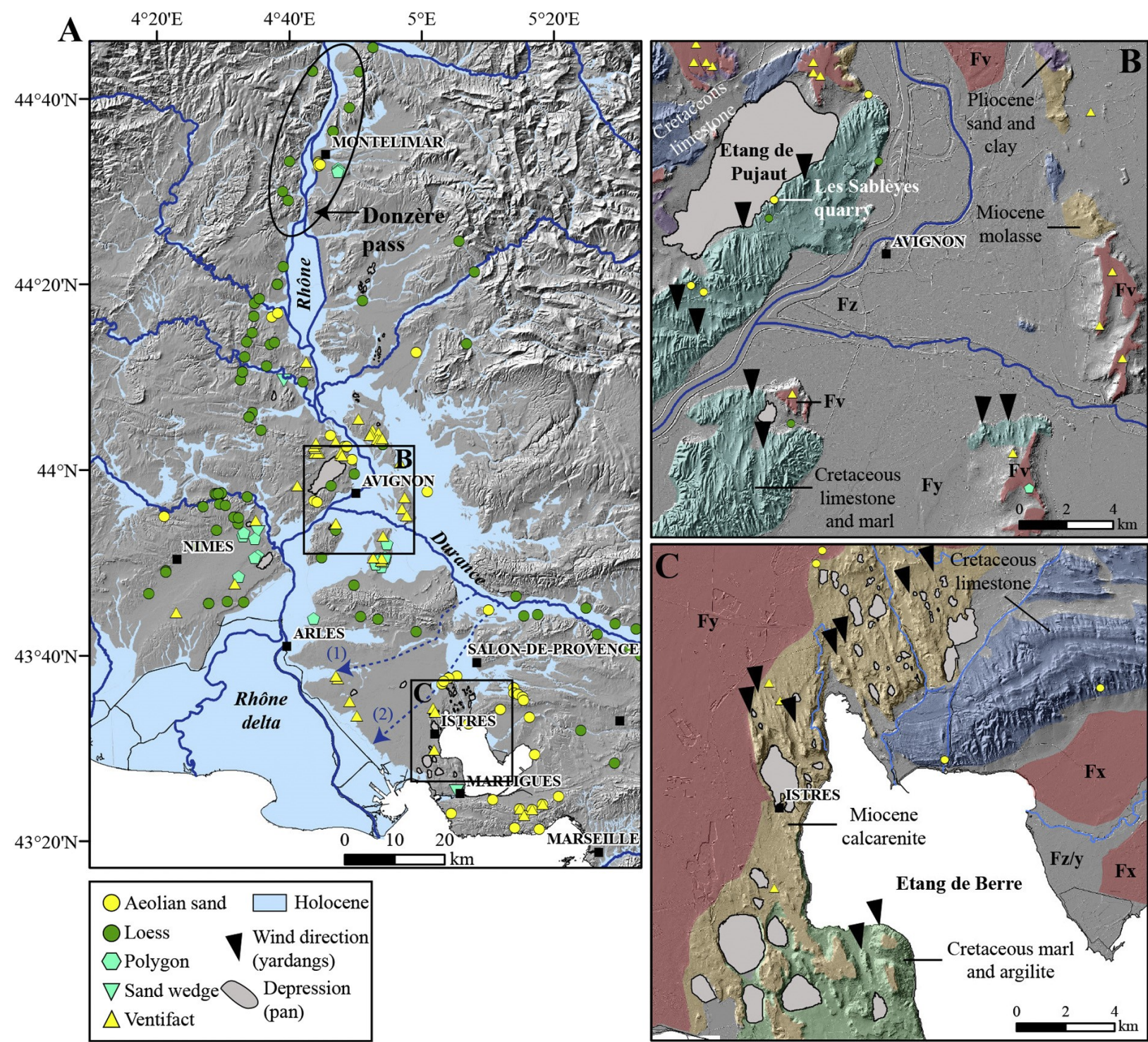

Fig. 3. (A) Spatial distribution of aeolian landforms and deposits in the middle and lower Rhône Valley (DEM $25 \mathrm{~m}$ from BD $\mathrm{ALTI}^{\circledR}$, http://professionnels.ign.fr). All geomorphological data plotted on the map are from the literature and new field survey: aeolian sand (Marcelin, 1926; Gabert-Delay, 1967; Damiani et al., 1980; Monjuvent et al., 1991; Ballais and Riser, 1996; Beeching et al., 2006; Ambert, 2013; this study), loess (Mazenot, 1956; Bonifay, 1962; Dubar, 1979; Beeching et al., 2006; Franc et al., 2017, rescue archaeology reports from http://dolia. inrap.fr), sand wedges and polygons (Bouteyre and Allemann, 1964; Cailleux and Rousset, 1968; Arnal, 1971a, 1971b; Andrieux et al., 2016a), and ventifacts (Mandier, 1984; Ambert, 2013; this study). The rectangles indicate the location of Fig. 4B and C. The black ellipse in the Montélimar area shows the narrowing of the valley. Blue arrows indicate the approximate flow direction of the palaeo-Durance River in the Crau Plain trough two gaps during the Pliocene (1) and Pleistocene (2) respectively. The abandonment of the Crau Plain by the river occurred between 75 and $35 \mathrm{ka}$ (Molliex et al., 2013); (B), (C) detailed topography of aeolian landforms (DEM $5 \mathrm{~m}$ from RGE ALTI ${ }^{\circledR}$, http://professionnels.ign.fr). The geological formations have been redrawn from the 1:50,000 geological map (infoterre.brgm.fr). Black arrows indicate palaeowind direction inferred from erosional landforms (yardangs) (see Fig.

$5)$.

\subsubsection{Yardangs}

Yardangs (Hedin, 1903) are elongated ridges created by aeolian abrasion in various lithologies (Laity and Bridges, 2013). In the lower Rhône Valley, their length exhibits strong variability and ranges between 61 to $1640 \mathrm{~m}$ (mean = $144 \mathrm{~m}$ ), and their width ranges between 28 and $638 \mathrm{~m}$ ( $\mathrm{mean}=118$ $\mathrm{m})$. The average length to width (L:W) ratio is $4: 1$ (Fig. 4C) in agreement with the wind tunnel experiments of Ward and Greeley (1984) and the measured values for Pleistocene yardangs in Spain (Gutiérrez-Elorza et al., 2002). 
The ridges are separated by narrow corridors with a U-shaped profile or a flat bottom. The corridors form a bypass sedimentary area where aeolian sands and loess did not accumulate. They are locally filled by lake, river, or slope deposits. The mean ridge direction shows values ranging from N160 to $\mathrm{N} 140$ and from N170 to N10 in the Istres and Avignon areas respectively (Fig. 4A, B). These preferred directions coincide with those of modern dominant winds (Fig. 2) and do not match the direction of the drainage system or the known faults.

The bedrock lithology largely influenced the formation and size of the corridors: sandy marls and calcarenites located to the west of the Étang de Berre lake (Istres) are characterized by significantly larger corridors than those formed in hard limestone (Fig. 3).

A $\mathrm{n}=28$

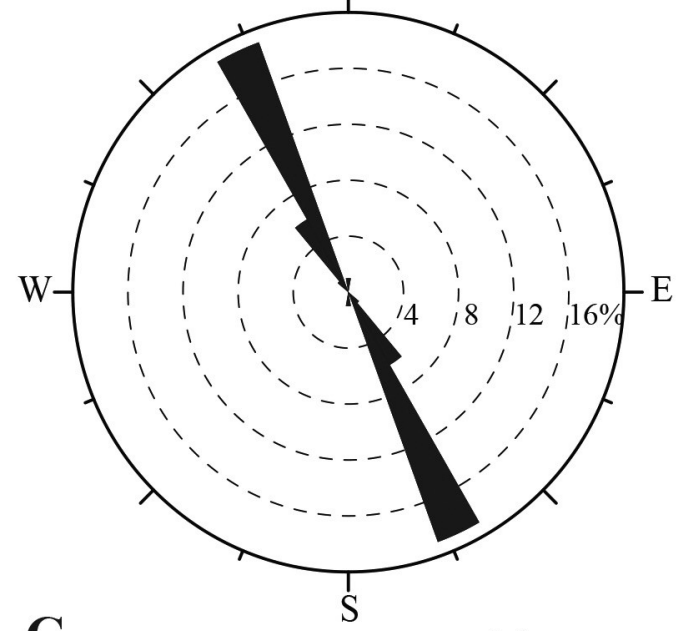

C

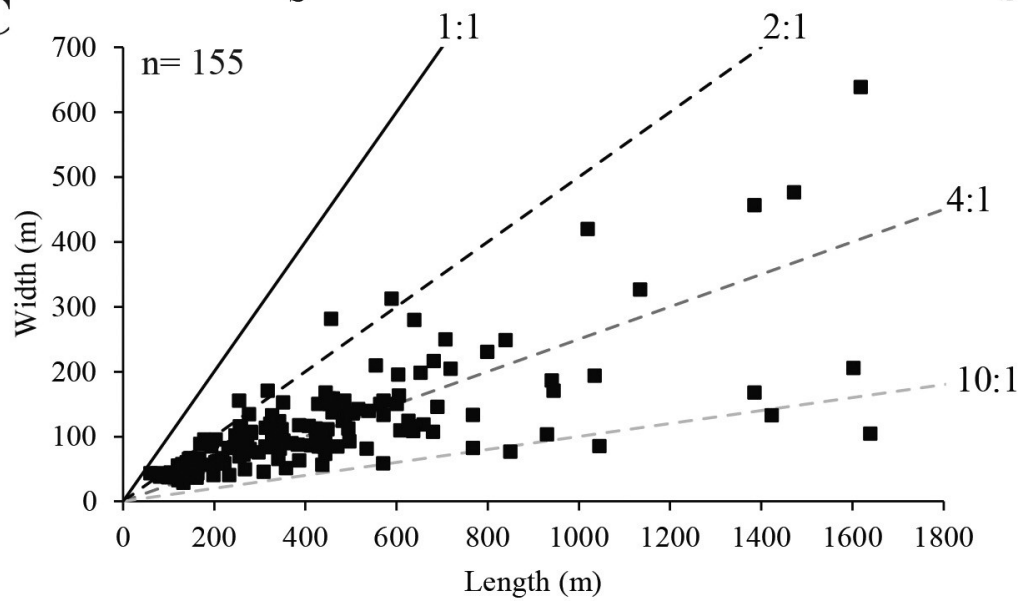

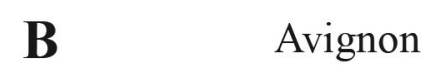

$\mathrm{n}=127$

Avignon

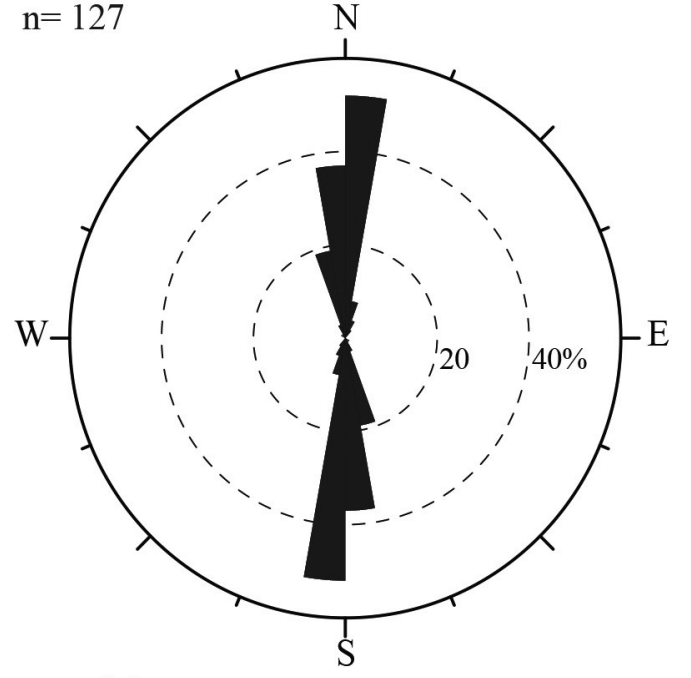

$2: 1$

(n)


and $200 \mu \mathrm{m}$; Ambert and Clauzon, 1992) and Cretaceous marls were highly sensitive to deflation. In contrast, the Cretaceous limestones were poorly affected.

\subsubsection{Ventifact pavements}

Ventifacts are wind-eroded rocks and pebbles characterized by a wide range of morphologies and lithologies but usually showing abrasion facets and pits or flutes (Laity, 1994; Laity and Bridges, 2013). For many decades, ventifacts have been documented on the alluvial terraces of the lower Rhône Valley (Cazalis De Fondouce, 1879; Arnal, 1971b, 1971a; Ambert, 1973, 2013; Chardon, 1975; Ambert and Clauzon, 1992). Additional sites were also identified during this study (Figs. 3, 5B). In several areas (e.g., Tavel, Pujaut), the ventifacts form a stone pavement on the surface of alluvial terraces (Fig. 5A). Such pavements that reach one or two pebbles thick are commonly described in cold (Mountney and Russell, 2004; Mackay and Burn, 2005) and warm (Adelsberger and Smith, 2009) deserts.
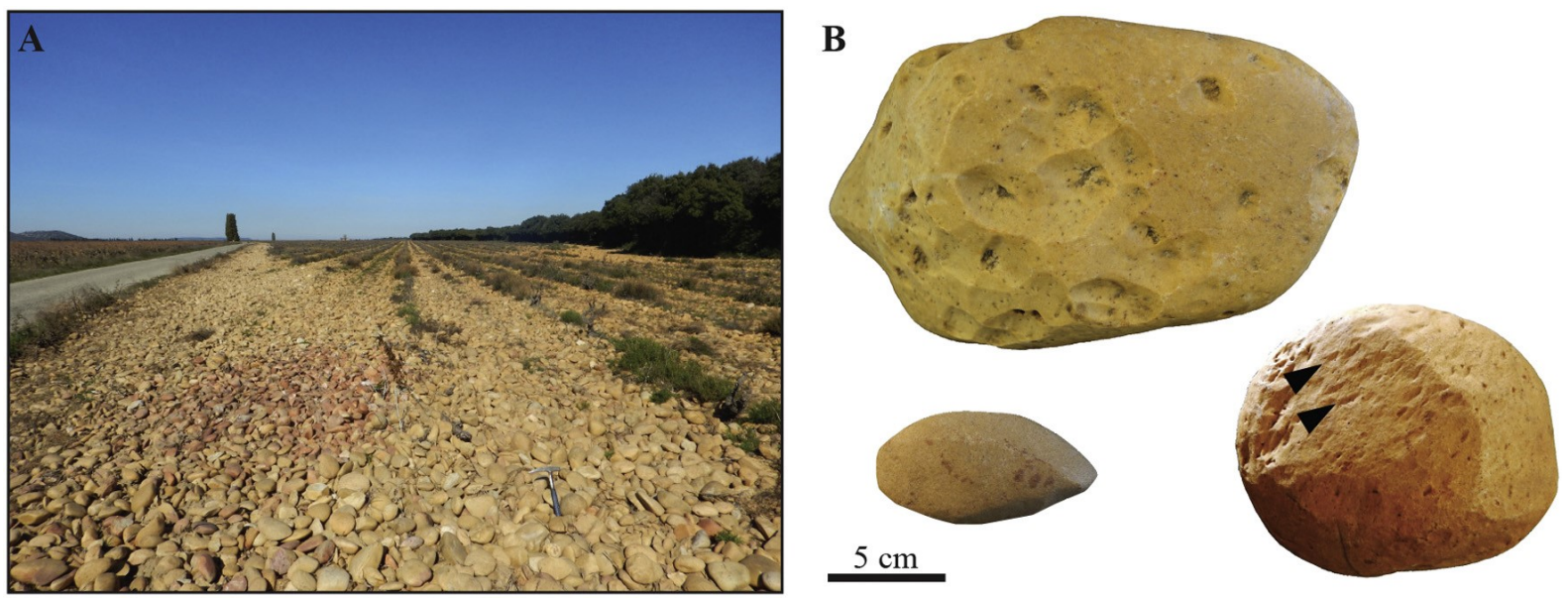

Fig. 5. (A) View of a desert pavement developed on a Pleistocene alluvial terrace near Tavel $\left(44.0307^{\circ} \mathrm{N}, 4.7096^{\circ} \mathrm{E}\right)$; (B) typical wind morphologies (facets, grooves, pits, wind flutes) on ventifacts. The black arrows show wind flutes on the windpolished surface.

\subsubsection{Inverted relief}

The Crau Plain comprises a succession of Plio-Pleistocene alluvial surfaces deposited by the palaeo-Durance River (Fig. 3) (Clauzon et al., 1990; Molliex et al., 2013). These surfaces are covered by abundant ventifacts (sometimes scattered in the ploughed layer), which are locally cemented by carbonates. They form an armoured surface lag protecting the underlying alluvial material from aeolian winnowing. The Plio-Pleistocene Crau Plain is located higher (up to N30 m along the banks of the Étang de Berre lake according to Ambert, 2013) than the strongly eroded surrounding Miocene lands and is probably an inverted relief of aeolian origin (Hörner, 1932; Goudie, 2013).

\subsection{Aeolian accumulation: sedimentary facies and architectural elements}

\subsubsection{Dunes}

To the east and south of the Étang de Berre lake, high-angle crossbedded (Sp) yellow fine sands have accumulated in dry valleys and at the northern footslope of limestone hills (Gabert, 1965; GabertDelay, 1967; Ambert, 1973, 2013). These deposits interpreted as slipface dunes reach $20 \mathrm{~m}$ in thickness. According to the composition of heavy mineral assemblages, Ambert (1973) suggested that sand was provided by the deflation of Miocene outcrops located north and west of the Étang de Berre lake (Fig. 3). These deposits were not observed during this study because of quarry abandonment.

\subsubsection{Sand ramps}

Metre-thick sand layers interbedded with diamictic layers cover the footslope of topographic obstacles (Fig. 6). The sand units account for N50\% in volume. These units include the following lithofacies: • High-angle $\left(\sim 30^{\circ}\right)$ cross-bedded sands $(\mathrm{Sp})$ composed of medium to coarse sand lenses 
(400 to $800 \mu \mathrm{m}$ ) 1-2 cm thick, with sometimes inverse grading, attributed to grainflow (Gf) (Hunter, 1977; Kocurek and Dott, 1981; Turner and Makhlouf, 2002) and more continuous laminated fine to medium sand beds $(200 \mu \mathrm{m})$ attributed to grainfall or climbing wind ripples $(\mathrm{Wr})$ (Hunter, 1977; Kocurek and Dott, 1981). We interpret these facies as small aeolian dunes with welldeveloped slipface prograding toward the relief (Fig. 6A, B).

- Massive fine sands or silty sands (Sm) with a thickness sometimes $\mathrm{N} 4 \mathrm{~m}$. This facies is interpreted as sandsheet deposited in a dry environment (Kocurek and Nielson, 1986).

- Massive, clast (Dcm) or matrix (Dmm) supported diamictic beds made up of poorly sorted limestone blocks and pebbles in a sandy matrix (Fig. 6A). The rock fragments are mainly angular and suggest limited transport. The basal limit is sharp and wavy. These facies are interpreted as debris flows. One- to two-metre-thick matrix to clast-supported diamictic beds, consisting of poorly sorted small pebbles (Dmm, Dcm), interlayered with fine to coarse sand beds (Sh) (Fig. 6D). The pebbles have a wide range of (mostly allochthonous) lithologies and a rounded shape. This suggests remobilisation of old alluvial deposits by slope processes. Locally, thin pebble layers or aligned granules are interpreted as lag deposits (Mountney and Russell, 2004; Ventra et al., 2017). This facies association probably has a polygenic origin (aeolian, debris flow, and overland flow) and reflects the interstratification of slope deposits supplied by the limestone relief and aeolian deposits spreading on the slope. It corresponds to sand ramps as described in modern deserts throughout the world (e.g., Lancaster and Tchakerian, 1996; Turner and Makhlouf, 2002; Bertram, 2003; Bateman et al., 2012; Telfer et al., 2012; Ventra et al., 2013, 2017; Kumar et al., 2017). Climbing sand ramps (dunes on the windward sides) and falling sand ramps (dunes on the leeward sides) are represented in the lower Rhône Valley (Fig. 6C). 

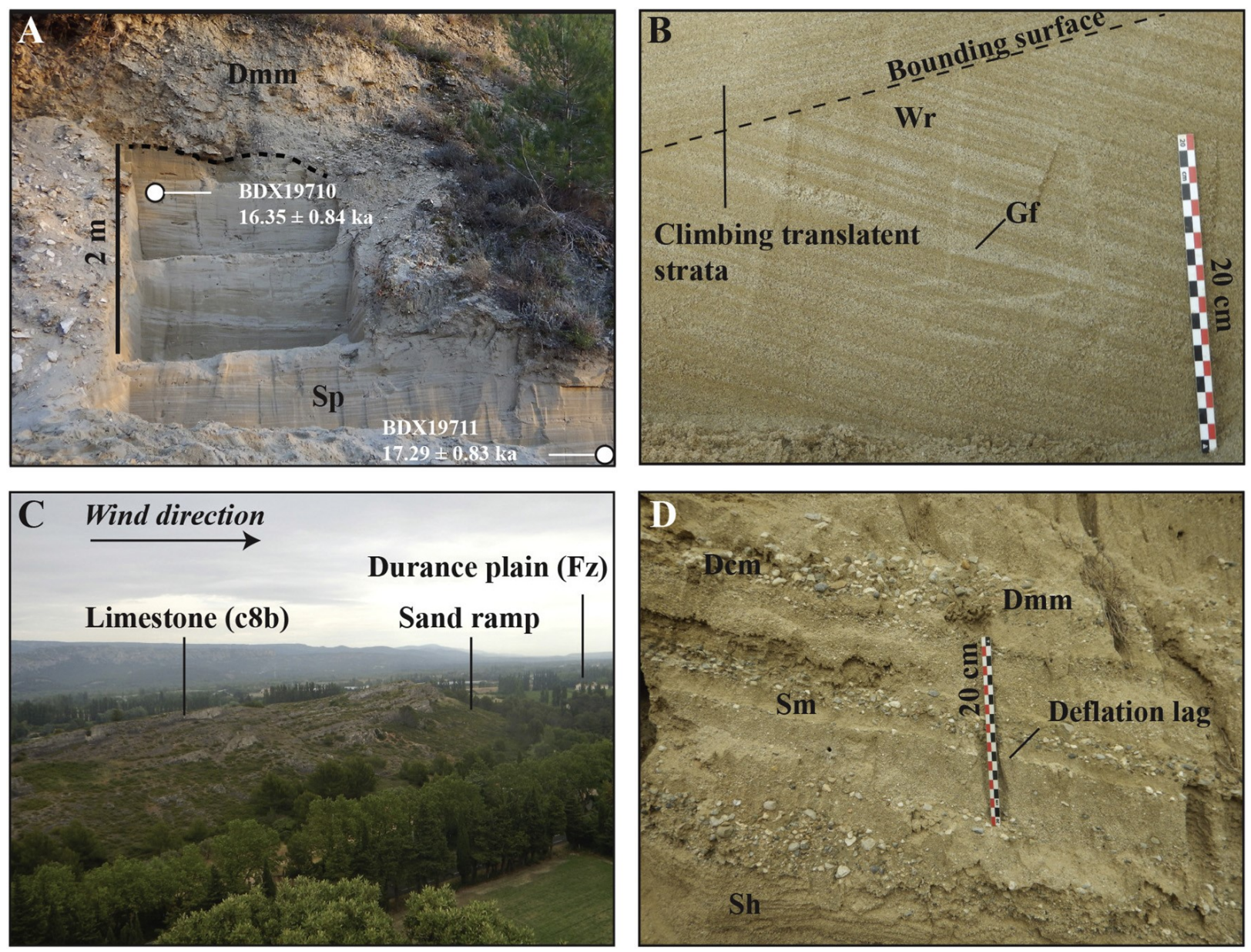

Fig. 6. Sand ramps lithofacies. (A), (B) High-angle cross-bedded sands ( $20^{\circ}$ ) viewed in a section subparallel (A) and perpendicular (B) to the transport direction. These lithofacies are interpreted as reflecting progradation of a climbing dune on the windward side of a topographic obstacle (Pujaut-Les Sablèyes quarry, $\left.43.9704^{\circ} \mathrm{N}, 4.7494^{\circ} \mathrm{E}\right)$. (C), (D) Cretaceous limestone relief ( $c 8 b$ on the geological map) with associated falling sand ramp on the leeward side. Closeup view of mixed sediment deposits (Pas des Lanciers quarry, $43.7339^{\circ} \mathrm{N}, 5.1289^{\circ} \mathrm{E}$ ). Dmm: matrix-supported layer, Dcm: clast-supported layer, Gf: grainflow, Sh: horizontally bedded sand, Sp: planar-cross bedded sand, Sm: massive sand, Wr: wind ripple (or grainfall deposit).

\subsubsection{Aeolian infilling of thermal contraction cracks}

Relict sand wedges forming polygon networks (visible in aerial photographs) develop in the Pleistocene alluvial terraces of the lower Rhône Valley (Fig. 3) (Bouteyre and Allemann, 1964; Cailleux and Rousset, 1968; Nury and Roux, 1969; Arnal, 1971a, 1971b; Andrieux et al., 2016a). These features are indicative of repetitive ground thermal contraction cracking in the context of deep seasonal freezing or permafrost (Murton, 2013; Andrieux et al., 2016b) near sand sources. The reconstruction of permafrost extension during the Last Glacial by Andrieux et al. (2016b) suggests, however, that perennial ice bodies were not able to develop in the ground in the study region. Therefore, the polygons are interpreted as being formed in a deep seasonal frost context caused by strong winter ground cooling events.

\subsubsection{Loessic sand}

This facies shows alternating massive calcareous brown-yellow fine silty sand beds (main mode 87 to $97 \mu \mathrm{m}$ ) and fine sands (114 to $136 \mu \mathrm{m}$ ) with abundant bioturbation (roots, burrows) and secondary carbonate concretions. The limits between the layers are diffuse and irregular probably because of bioturbation. These deposits correspond to transitional facies between aeolian sands and 
loess. Similar deposits have been observed along the margin of the North European Sand Belt (NESB) (Paepe and Vanhoorne, 1967; Lautridou, 1984) and in southwest France (Sitzia et al., 2017).

\subsubsection{Primary loess}

Primary loess is characterized by massive calcareous yellow-brown (10YR $5 / 4$ to $10 \mathrm{YR} 6 / 4$ ) to brown (7.5YR 5/4) coarse silts. The thickness ranges from b1 to $10 \mathrm{~m}$ (Fig. 7A, B). Bioturbation and secondary carbonate concretions are abundant. Poorly developed palaeosols are sometimes visible within the deposit (Fig. 7C).
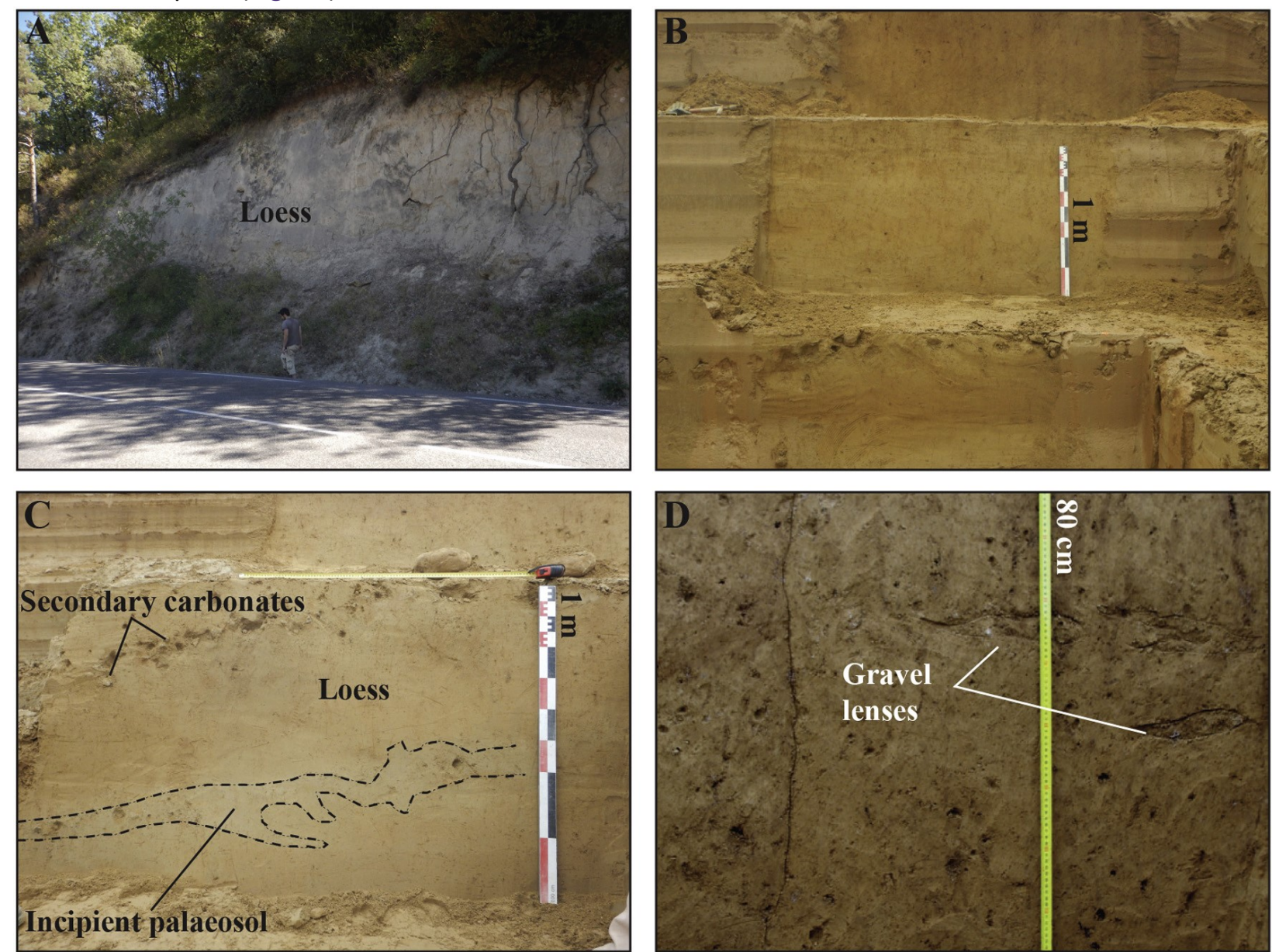

Fig. 7. Loess lithofacies. (A) View of thick primary loess deposits ( $\mathrm{N} 6 \mathrm{~m}$ ) near Saint-Paul-les-Durance (Provence). The person $(1.80 \mathrm{~m})$ makes the scale. (B), (C) Yellow-brown calcareous sandy loess with abundant bioturbation and a weakly developed palaeosol stretched along the slope. Secondary carbonates correspond to centimetric loess dolls (Lautagne, $44.9039^{\circ} \mathrm{N}$, $4.8964^{\circ} \mathrm{E}$ ). (D) Secondary loess deposits showing decimetric gravel lenses (Garons, $43.7564^{\circ} \mathrm{N}, 4.4377^{\circ} \mathrm{E}$ ).

\subsubsection{Secondary (reworked) loess}

Massive coarse silts showing poor sorting and scattered gravel or gravelly lenses (Fig. 7D) are interpreted as colluviated loess. The deposits are less calcareous and contain brick, pottery, and charcoal fragments. This facies is thought to be related mainly to the erosion of primary loess caused by overland flow and agricultural practices during the Holocene (Catt, 2001).

\subsection{Spatial distribution of aeolian landforms and deposits}

The map of aeolian deposits in southeast France derived from the LUCAS database is illustrated in Fig. 8. Validation tests were conducted to compare the map with (i) the location of 256 cross sections of aeolian deposits described in the literature (Marcelin, 1926; Mazenot, 1956; Bonifay, 1962; Gabert- 
Delay, 1967; Dubar, 1979; Damiani et al., 1980; Monjuvent et al., 1991; Ballais and Riser, 1996; Beeching et al., 2006; Ambert, 2013; http://dolia.inrap.fr) or identified during this work (Table A.1); and (ii) the already available conventional maps (Fig. A.3). To overcome the poor precision of the location of cross sections, a buffer area of $1000 \mathrm{~m}$ radius was fixed around each mentioned site. The analysis shows that $84.4 \%$ of the observation points $(n=216)$ fall within the aeolian units mapped by our study. This significantly improves the results obtained with conventional maps. Three maps were used for the test. The oldest was published by Suen (1934); the second is the European loess map by Haase et al. (2007), and the last is the 1:50,000 geological map of France of BRGM (http://infoterre.brgm.fr/). The aeolian units mapped incorporate respectively $32.8 \%(n=84), 30.1 \%$ $(n=77)$ and $48.0 \%(n=123)$ of the described cross sections.

Comparison between the LUCAS-derived map and the BRGM map also shows that $85.0 \%$ of the areas of aeolian units reported by the latter are well identified by the new approach. The new map suggests, however, that aeolian deposits are more widespread south of Valence than indicated by the BRGM map (Fig. A.3). Some limited areas are classified differently. The differences are mainly caused by the low resolution of LUCAS data and the issue arising from the difficulty to identify small deposits in areas with contrasted relief or to incomplete mapping in the conventional approach.

The aeolian deposits overlay a wide variety of material (alluvial terraces, limestones, molasses) and cover an area of ca. 12,000 $\mathrm{km}^{2}$. Their thickness ranges between several metres (locally $\mathrm{N} 10 \mathrm{~m}$ ) to $\mathrm{b} 1 \mathrm{~m}$. The following observations can be made from the map (Fig. 8):

- A transition between an area with dominantly coarse loess and an area of typical loess (i.e., finergrained loess similar to the NELB loess) occurs around latitude $45^{\circ} \mathrm{N}$.

- Loess and sandy loess deposits form an almost continuous cover on the plateaus in the northern area (e.g., Dombes plateau) and have a patchier distribution to the south, especially along the Durance and Ardèche rivers. In mountainous areas, such a distribution may be partly caused by poor mapping accuracy as a result of uneven relief.

- In the periphery of the lower Rhône Valley, the grain size of aeolian deposits decreases gradually to the west and to the east. The alluvium is thus assumed to be the main source of dust.

- The sandy deposits are mainly located in a narrow band along the Rhône River between Avignon and Montélimar (near latitude $44^{\circ} \mathrm{N}$ ), in the Costières de Nîmes area and in the periphery of the Étang de Berre lake.

- The distribution of ventifacts, yardangs, and pans is not random. They are concentrated south of latitude $44^{\circ} \mathrm{N}$ along the valley axis (Fig. 3). Ventifacts are located mainly on old alluvial plateaus (Fv). 


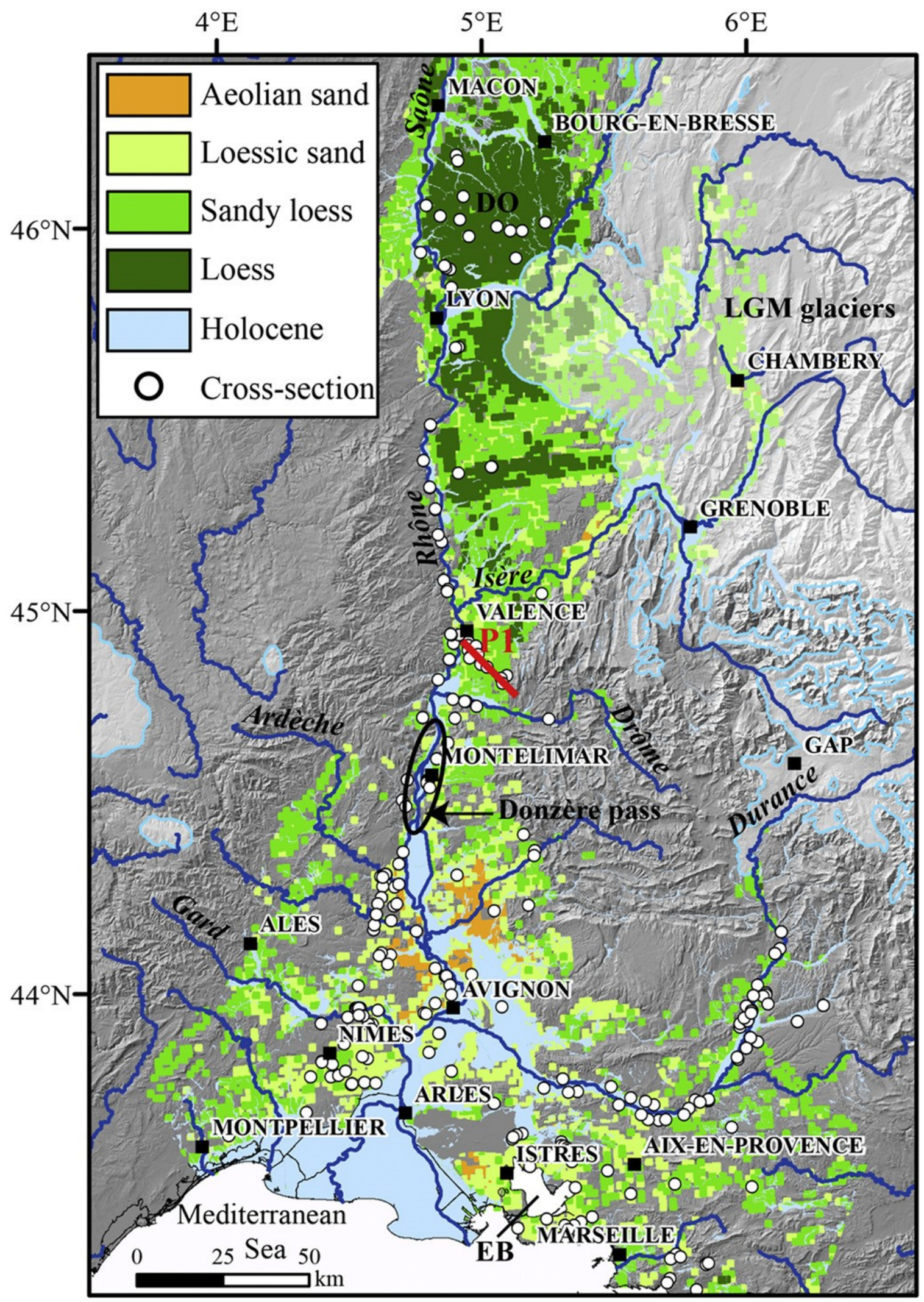

Fig. 8. Distribution of aeolian deposits derived from the LUCAS topsoil database. All the loess and sand cross sections from the literature and new field survey are indicated (see Table A.1). Profile 1 (P1) is shown in Fig. 11. 


\subsection{Grain-size distribution and gradients}

The grain-size curves of 63 samples of primary loess show a polymodal distribution with five subpopulations (Fig. 9A), which are (in decreasing order of contribution): (i) fine sands to coarse silts between 50 and $75 \mu \mathrm{m}$ (mean $62 \mu \mathrm{m}$ ); (ii) medium silts between 12 and $18 \mu \mathrm{m}$ (mean $14.3 \mu \mathrm{m}$ ); (iii) clays (mean $3.1 \mu \mathrm{m}$ ); (iv) medium sands $(220 \mu \mathrm{m})$; and (v) ultrafine particles $(0.4 \mu \mathrm{m})$. Secondary loess has similar grain-size distribution and modes but with poor sorting (Fig. 9B). Loessic sands also have a polymodal distribution with a coarse mode ranging from 87 to $136 \mu \mathrm{m}$ (Fig. 9C). Sandy deposits have a predominantly unimodal grain-size distribution (Fig. 9D) with a mode between 235 and $834 \mu \mathrm{m}$.

The grain-size data extracted from the LUCAS database along a NWSE profile in the east of Valence show a gradual decrease in sand content and an increase in silt content away from the river (Fig. 10A). The coefficient of determination $\left(r^{2}\right)$ ranges from 0.36 to 0.38 , and the relationship between these patterns and the distance to the river is significantly correlated ( $p$-value b0.05, nonparametric test of Kendall's rank correlation) (Fig. 10). The profile indicates that the transition between sandy loess and loess occurs over a much shorter distance than in northern France (18 km vs. 65 km) (Fig. 10B).
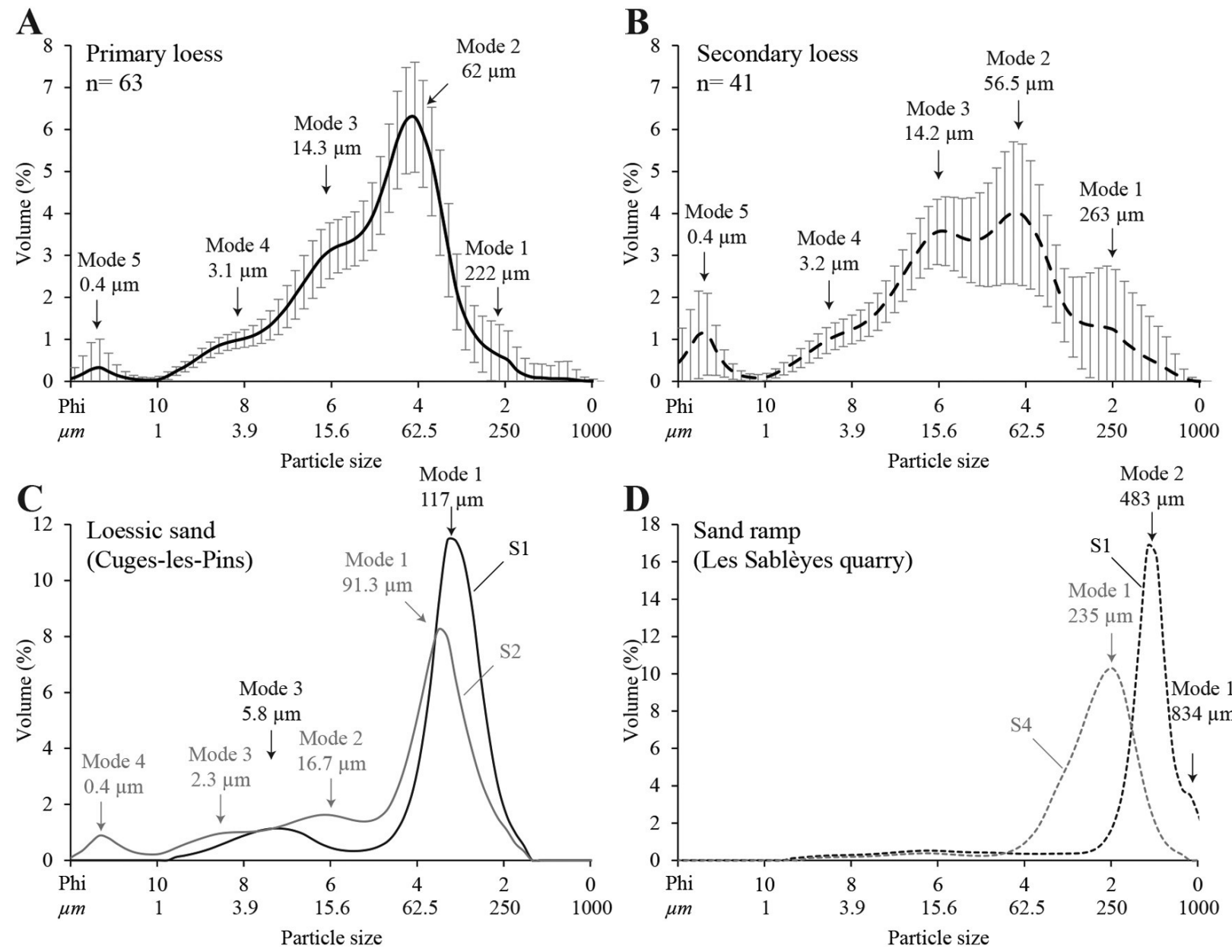

Fig. 9. (A), (B) Mean grain-size distribution of primary and secondary loess deposits with their standard deviation

(B), (C) Grain-size distribution of some representative samples of sandy loess and aeolian sands. The mean modes were determined using parametric curve-fitting using R package mixdist (Macdonald and Du, 2012). 
A
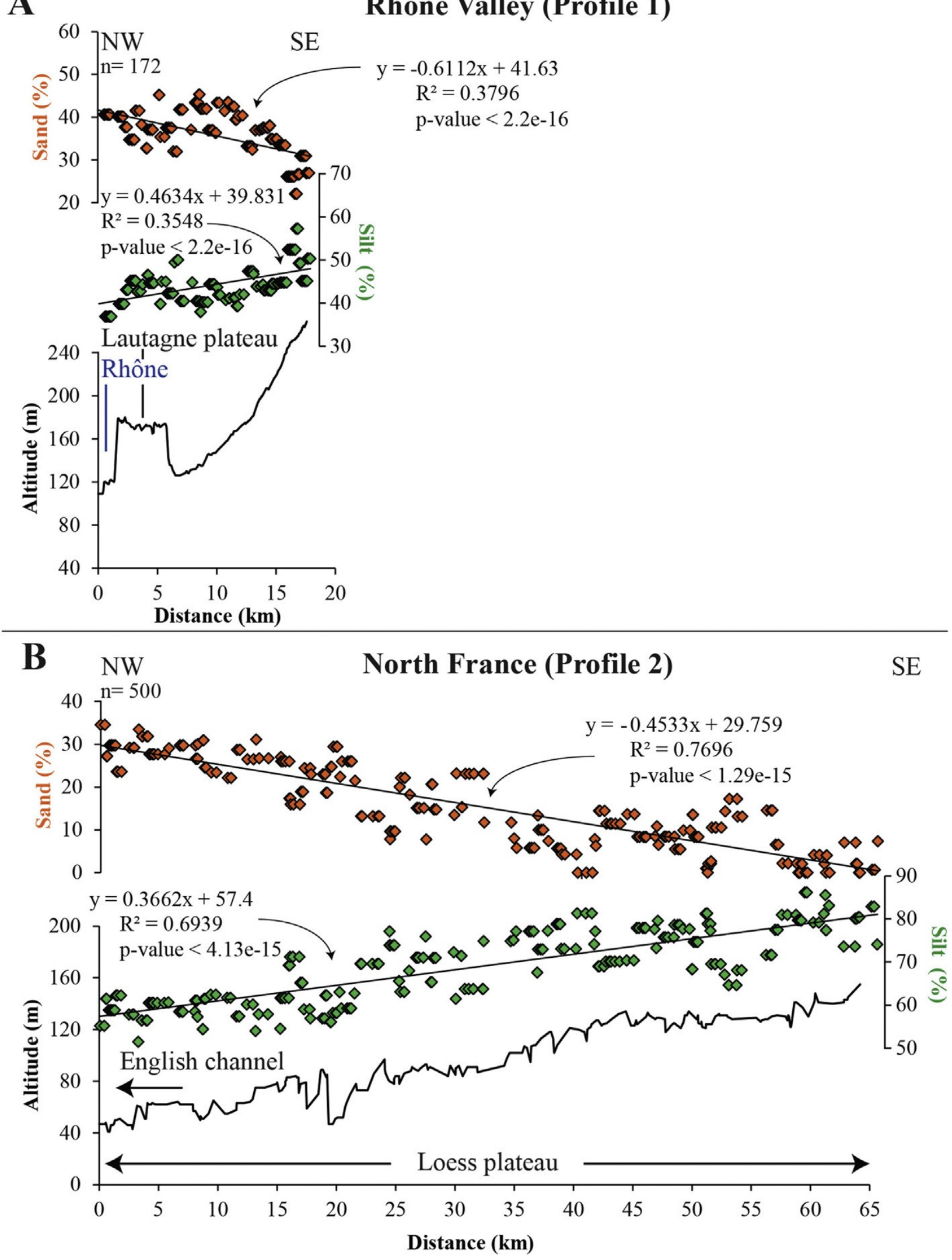

Fig. 10. Grain-size evolution of aeolian deposits along two profiles in the Rhône Valley (A) and northern France (B) shown in Figs. 9 and 12. The data are from the LUCAS topsoil database. 


\subsection{Chronology}

Overall, the number of available numerical ages is limited. The radiocarbon ages recently obtained on calcitic granules secreted by earthworms in the loess of Lautagne near Valence (Ronco et al., in press) indicate that dust accumulation mostly occurred between 27 and $16 \mathrm{ka}$ cal. BP. The OSL dating on quartz grains ( $45-63 \mu \mathrm{m}$ ) of the Garons loess yielded an age of $27 \pm 1.5 \mathrm{ka}$ (M. Rué, personal communication). These results are compatible with older data from the Provence and Ardèche areas,

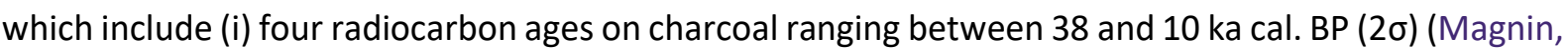
1992; Onoratini et al., 1999; Bazile, 2007), and (ii) 11 radiocarbon and OSL ages on palaeosols ranging from 41 to 20 ka (Magnin, 1992, 2014; Ambert, 2013; Franc et al., 2017).

The available ages for the sandy deposits remain scarce so far. Only two radiocarbon datings from red colluvium interstratified within dune sand gave an MIS 3 age (41 and 29 ka cal. BP; Ambert, $1974,2013)$. The OSL measurements on the coarse grain $(125-160 \mu \mathrm{m})$ quartz fraction in this study at the Les Sablèyes quarry indicate a phase of dune emplacement during MIS 2 (BDX19711: $17.29 \pm 0.83$ ka; depth: $4.5 \mathrm{~m}$; and BDX19710: $16.35 \pm 0.84 \mathrm{ka}$; depth: $1.5 \mathrm{~m}$ ). Both ages are indistinguishable within $2 \sigma$ error margins, however, with a slightly younger age for the uppermost sample (BDX19710) (cf. Appendix B for more details).

\section{Discussion}

\subsection{The aeolian system of the Rhône Valley}

At the regional level, the spatial distribution of aeolian landform and deposits is not random. Two zones can be distinguished: (i) an area located north of a succession of narrowings of the Rhône Valley (e.g., the Donzère Pass) between latitudes $45^{\circ} \mathrm{N}$ and $44^{\circ} \mathrm{N}$; (ii) a more southern area typified by valley widening, which forms a triangle open to the Mediterranean Sea.

In the northern area, no aeolian landforms were identified. The aeolian deposits are mainly loess covering the plateaus and slopes of the main valleys. The boreholes listed in the BRGM database (http://infoterre.brgm.fr/) show that the loess reaches locally a thickness N15 m on the windward side of the Dombes plateau. The conceptual models proposed by several authors (Mason et al., 1999; Wiggs et al., 2002; Sweeney et al., 2005; Lehmkuhl et al., 2016) suggest that wind deceleration on the plateaus bordering large rivers allows significant accumulation of dust. Sandy deposits (dunes, coversands) are scarce along the middle reach of the Rhône River supposedly because of river entrenchment and the limited space available for accumulation.

In the southern area, the aeolian landforms (yardangs, pans, desert pavements) and the sandy deposits (dunes, sand ramps, sand wedges) are abundant and indicate that sand transport by saltation was substantial over vast areas. According to McCauley et al. (1977), Laity (2009), and Sebe et al. (2011), the formation of yardangs also implies strong unidirectional and constant winds. Such winds are explained by the narrowings of the Rhône Valley, which channel and accelerate the air masses coming from northern Europe. The measurements of yardang orientation indicate winds coming from the north as for the modern Mistral. Compared to the present, mean wind speeds were probably higher during the glacial caused by increased cyclonic activity in Europe linked to the ice sheets on the British Islands and Scandinavia (Isarin et al., 1997; Christiansen and Svensson, 1998; Christiansen, 2004).

The distribution of aeolian deposits strongly suggests that the floodplain of the Rhône River, which is parallel to the direction of prevailing winds (N-S to NW-SE), was the main source of particles. Widening of the valley to the south led to increasing in the surface of the alluvial material exposed to deflation and in the available space for sand deposition. Other potential sources of particles are the unconsolidated Miocene molasses (sandstones, calcarenites, sandy marls) where wind carved 
depressions and yardangs. The contribution of these sources remains difficult to estimate but was probably minor in comparison with the inputs from the Rhône floodplain.

Despite the widespread occurrence of yardangs and ventifacts, which testifies that sand transport was very efficient (Knight, 2008; Laity, 2009), the deposition of windblown sand was limited in the study area. This suggests a negative sediment budget (Kocurek and Havholm, 1993), and the lower Rhône Valley likely served as a bypass surface between the sedimentary sources and sinks (Knight, 2008). The rare sand accumulations preserved correspond either to small dunes on the banks of the Rhône River or sand ramps trapped at the foot of topographic obstacles. In the periphery of the Rhône corridor, the grain size decreases rapidly eastward and westward and is discontinuous, but locally thick sandy loess deposits were formed. Loess becomes finer and thinner laterally to give way to soils enriched with aeolian particles (soil contamination; Yaalon and Ganor, 1973).

The Carpathian Basin (Hungary) is an example of a Pleistocene aeolian system sharing some features with the Rhône system and probably associated with similar semiarid climate conditions (RuszkiczayRüdiger et al., 2011; Sebe et al., 2011, 2015). This basin is swept by a unidirectional northerly wind channelled by the mountains and includes ventifact pavements, pans, and yardangs upstream while parabolic dunes form extensive fields downstream (Sebe et al., 2011; Györgyövics and Kiss, 2013; Buró et al., 2016). In the periphery of sandy deposits, loess is also present over large areas (Lindner et al., 2017). By comparison, the Rhône Valley appears to be an incomplete aeolian system. Two hypotheses may explain the lack of significant sand accumulation: (i) a poor preservation of the deposits caused by subsequent erosion during the Holocene, particularly caused by strong anthropogenic landscape modification since the Neolithic (however, this phenomenon is assumed to have had only a limited impact); and (ii) sea level rise during the Late Glacial and the Holocene leading to the submersion of the continental shelf and associated dune fields. As shown by Bassetti et al. (2006) and Jouet et al. (2006), the continental shelf of the Gulf of Lion is covered by sand layers dated to 45 to 20 ka cal. BP, which in large part could be part of aeolian origin.

In summary, the Rhône Valley is an aeolian system characterized by (i) strong unidirectional winds channelled by the relief; (ii) abundant deflation landforms; (iii) a major fluvial axis (the Rhône River) with the capacity to provide to the wind significant amounts of sedimentary material.

\subsection{Loess depositional context}

Many authors (Alimen, 1965; Dubar, 1979; Coudé-Gaussen, 1990) have pointed out that perimediterranean loess displays distinctive sedimentological characteristics when compared to loess from the NELB, mainly a coarser texture and higher carbonate content. The aeolian deposits of the Rhône Valley also show that the spatial distribution and facies differ significantly.

\subsubsection{The origin of polymodality}

The loess samples from the study area all have a trimodal grain-size distribution (Fig. 9A) with a coarse mode (mode 1, 50-75 $\mu \mathrm{m}, 63 \pm 9 \%$ ), a medium mode (mode 2, 12-18 $\mu \mathrm{m}, 25 \pm 8 \%$ ) and a fine mode (mode $3, \sim 3 \mu \mathrm{m}, 6 \pm 2 \%)$. In addition, ultrafine (b1 $\mu \mathrm{m})$ and very coarse ( $200 \mu \mathrm{m})$ particles are present in small proportion. These last two populations were probably not transported as dust. According to Paton (1978) and Bronger and Heinkele (1990), the particles b1 $\mu \mathrm{m}$ are related to weathering and pedogenesis, while the coarse particles may correspond to ferruginous nodules, secondary carbonate concretions, or earthworm calcitic granules. However, inputs by saltation from local sand sources (molasses) cannot be excluded.

The main grain-size modes suggest different transport and deposition mechanisms (Middleton, 1976; Ashley, 1978; Bagnold and Barndorff-Nielsen, 1980). Coarse particles (N20 um) are 
transported at low altitudes by saltation or short-term suspension. In contrast, fine particles (b20 $\mu \mathrm{m})$ experience long-term suspension in the atmosphere at high altitudes (Tsoar and Pye, 1987; Pye, 1995; Kok et al., 2012; Újvári et al., 2016). Many loess in the world have a bimodal distribution, which is generally assumed to come from the mixing of two populations provided by different sources (e.g., Pye and Zhou, 1989; Sun et al., 2002, 2004; Lim and Matsumoto, 2006; Muhs and Benedict, 2006; O'Hara et al., 2006; Vandenberghe, 2013; Ben-Israel et al., 2015). By analogy, the coarse mode (50-75 $\mu \mathrm{m}$ ) of the loess of the Rhône Valley would correspond to proximal sources, whereas the modes in fine silt $(12-18 \mu \mathrm{m})$ and clay $(\sim 3 \mu \mathrm{m})$ would come from more distant sources. The measurements made during dust storms by McTainsh et al. (1997) seem to confirm these hypotheses. These authors observed the simultaneous transport of coarse particles $(50-70 \mu \mathrm{m})$ from a local source, of mediumsized particles $(20-40 \mu \mathrm{m})$ in dust plumes from a regional source and of fine particles that travelled over long distances in the atmosphere (continuous background dust rain). However, there is no full consensus on the origin of loess bimodality. The observations by Lin et al. (2016) in the Celé oasis (China) suggest that the fine and coarse dust components trapped in the oasis during storm episodes come from a single source, the Taklamakan Desert. The coexistence of two modes is explained by the authors as resulting mainly from grain-size sorting during accumulation as a consequence of fluctuations in wind speed. Similarly, Bullard and Austin (2011) showed that the windblown material from outwash deposits in Greenland had a multimodal distribution.

A multimodal grain-size distribution of loess is not the most common in Europe. Loess from northern Europe, central Europe, and the perimediterranean area exhibits mostly a unimodal or a bimodal distribution (e.g., Crouvi et al., 2008; Enzel et al., 2010; Novothny et al., 2011; Varga et al., 2012; Vandenberghe, 2013; Vandenberghe et al., 2014; Krauß et al., 2016). Loess from the Rhône Valley also have a distinctively coarser mode (50-75 vs. 35-40 $\mu \mathrm{m}$; Vandenberghe, 2013). Coarse loess has been described by authors in central Europe; in the immediate vicinity of the Danube River (Novothny et al., 2011) and one of its tributaries, the Tisza River (Bokhorst et al., 2011); in perimediterranean regions in the periphery of dune fields (Crouvi et al., 2008; Amit et al., 2011); and in transitional facies in a narrow stripe between coversands and typical loess in the NELB (Vandenberghe et al., 1985).

The mode between 12 and $18 \mu \mathrm{m}$ is typical of Hungarian aeolian red clays dated to the lower Pleistocene (Kovács, 2008; Kovács et al., 2011; Varga, 2011). According to Varga et al. (2016), this dust may have a Saharan origin, with a contribution ranging from $20 \%$ to $30 \%$ in the Carpathian Basin. Saharan dust inputs have also been identified in loess from Israel but as finer-grained particles (3-8 $\mu \mathrm{m}$ ) (Crouvi et al., 2008; Ben-Israel et al., 2015). For the loess of the Rhône Valley, attributing a grainsize population to a well-defined source is difficult in the absence of geochemical or mineralogical analysis. The different modes may derive from a single local source according to the model proposed by Lin et al. (2016) or may correspond to distinct regional sources (even possibly remote sources such as Saharian).

The $3 \mu \mathrm{m}$ mode has been reported in almost all European loess and indicates transport by longterm suspension in the atmosphere from either regional or very distant (supracontinental) sources (continuous background dust rain).

\subsubsection{The central role played by vegetation in loess deposition}

Several arguments are in favour of the crucial effect of vegetation on loess accumulation in the Rhône Valley. Rapid trapping of coarse particles near sources by plants may explain some of the loess characteristics. These arguments include (i) the efficiency of vegetation to trap aeolian particles; (ii) the persistence of a dense local vegetation cover in an area considered as a refuge during the LGM; and (iii) the geometry and grain size of the deposits.

5.2.2.1. Efficiency of dust entrapment by vegetation. 
As early as in the 1980s, Danin and Yaalon (1981) highlighted the crucial role played by mosses in dust trapping in a peridesertic environment without topographic obstacles. The role of vegetation in preventing particle remobilization by wind or overland flow was also emphasized (Danin and Ganor, 1991; Wolfe and Nickling, 1993). Several field and wind tunnel experiments showed that the vegetation cover contributes to the increase in the surface roughness length $\left(z_{0}\right)$ and in the wind shear velocity threshold (U⿴囗十) (Wolfe and Nickling, 1996; Lancaster and Baas, 1998; Hoffmann et al., 2008; Field et al., 2012). For example, Hoffmann et al. (2008) measured an exponential increase of $z_{0}$ in relation to vegetation height $(\mathrm{h})$ with $\mathrm{z}_{0}$ ranging from 0.06 to $0.14 \mathrm{~cm}$ for nearly bare soil $(\mathrm{h}=2.5 \mathrm{~cm})$ and from 0.90 to $3.98 \mathrm{~cm}$ for high grass $(\mathrm{h}=27.5 \mathrm{~cm})$. The height and also the density of plant cover are determinant factors in the sedimentation rate (Leenders et al., 2007; Field et al., 2012; Youssef et al., 2012). Raupach et al. (2001) highlighted the role played by the optical porosity $(\tau)$ of windbreaks (i.e., vegetation) on dust entrapment. Optimal values $(\tau \approx 0.2)$ were obtained with a windbreak dense enough to efficiently retain the particles but sparse enough to allow the air to flow through (Raupach et al., 2001). When the dust-loaded flux passes through the obstacle, the particles are filtered and deposited on the vegetation. The same authors noticed the efficiency of the low-hanging branches of shrub on trapping sediment drifting close to the ground by saltation or modified suspension. In conclusion, a mix of shrub and tree patches is a much more effective dust trap than steppe or tundra because of greater roughness (Thom, 1975; Tsoar and Pye, 1987).

\subsubsection{The persistence of dense vegetation cover in the Mediterranean area during the LGM.}

According to some authors (e.g., Tzedakis et al., 2013), the study area acted as a refugium for vegetation during the coldest periods of the glacial. Despite the low number of available data (Beaulieu et al., 2005), the pollen records suggest that forest (Picea, Abies, deciduous Quercus, mesothermophilous taxa) persisted in the Mediterranean regions during the LGM (González-Sampériz et al., 2005, 2008; Beaudouin et al., 2007). This hypothesis is consistent with the simulated vegetation cover using global climate models (GCMs) (Cheddadi et al., 2006; Arpe et al., 2011; Strandberg et al., 2011), which indicate the persistence of a climate more favourable to tree growth than in northern France (Fig. 12). The studies by Médail and Diadema (2009) also suggested that the Mediterranean region provided locally good conditions for plant biodiversity at medium altitude, particularly along deeply incised valleys. The persistence of tree stands along rivers had necessarily a significant impact on aeolian dynamics. In arid and semiarid environments, the water table level decreases with distance from the river, resulting in a gradual decrease in plant cover and subsequent increase in the exposure of soils to deflation (Aishan et al., 2013; Kuba et al., 2013).

\subsubsection{Geometry and loess grain-size.}

The loess from the Rhône Valley has distinctive characteristics compared to NELB. These are (i) strong local thickness but discontinuous distribution, (ii) coarse grain size rapidly decreasing with increasing distance to the river, and (iii) significant bioturbation. The thick (often N5 m) and discontinuous loess forms wedge-shaped deposits in small areas close to major rivers. According to Tsoar and Pye (1987), Pye (1995), and Hugenholtz and Wolfe (2010), such a pattern is typical of loess accumulation in a densely vegetated environment. Vertical accretion means that vegetation is capable to grow as loess accumulates (Pye, 1995). The heterogeneous spatial distribution reflects preferred particle entrapment in the densest patches of vegetation (Fig. 11A). Bioturbation (rhizoliths, burrows) also argues in favour of abundant vegetation contemporaneous to loess accumulation.

In this context, dominantly coarse loess is assumed to reflect the simultaneous entrapment by vegetation of sand and coarse silt migrating in saltation and modified suspension from the floodplain (Fig. 11A). Xu et al. (2016) also showed that the dust trapped during storms in the Céle oasis had a coarse mode, which ranged between 53 and $81 \mu \mathrm{m}$ depending on the season. In contrast, the northern 
European plains are typified by more continuous loess deposition over the landscape, well-developed grain-size gradients, and finer-grained loess (Fig. 10B). Such a pattern results from the lack of forced deposition by vegetation close to the sources, allowing better sorting of the particles by the wind (Fig. 11B).

(A) Rhône Valley: dust trapping by vegetation near the source

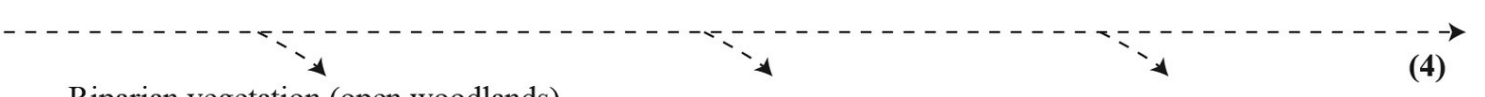

Riparian vegetation (open woodlands)

(3)

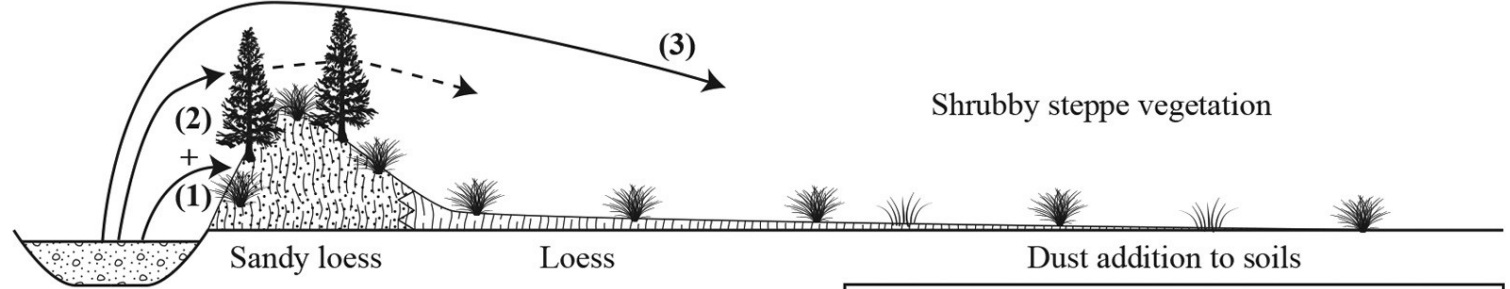

Dust source

(1) Sand and very coarse dust (saltation, modified saltation)

(2) Coarse and medium dust (short-term suspension)

(B) North European Sand and Loess Belt: no obstacles

(3) Fine dust (long-term suspension)

(4) Very fine dust (background dust)

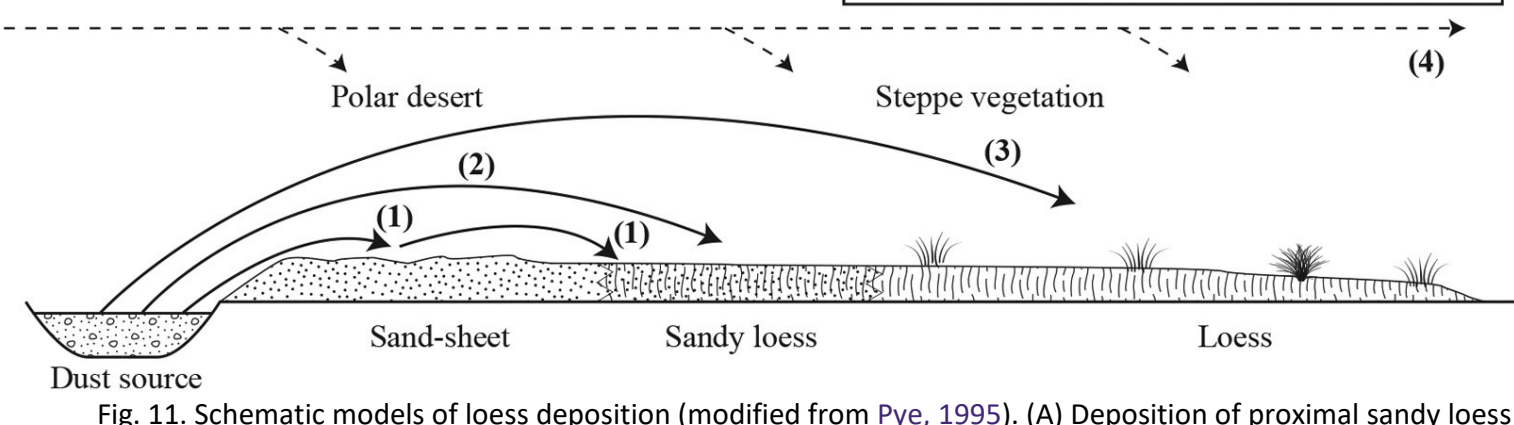
on a densely vegetated (shrubs, trees) surface adjacent to a dust source; (B) separate deposition of sand and loess in a poorly vegetated landscape 

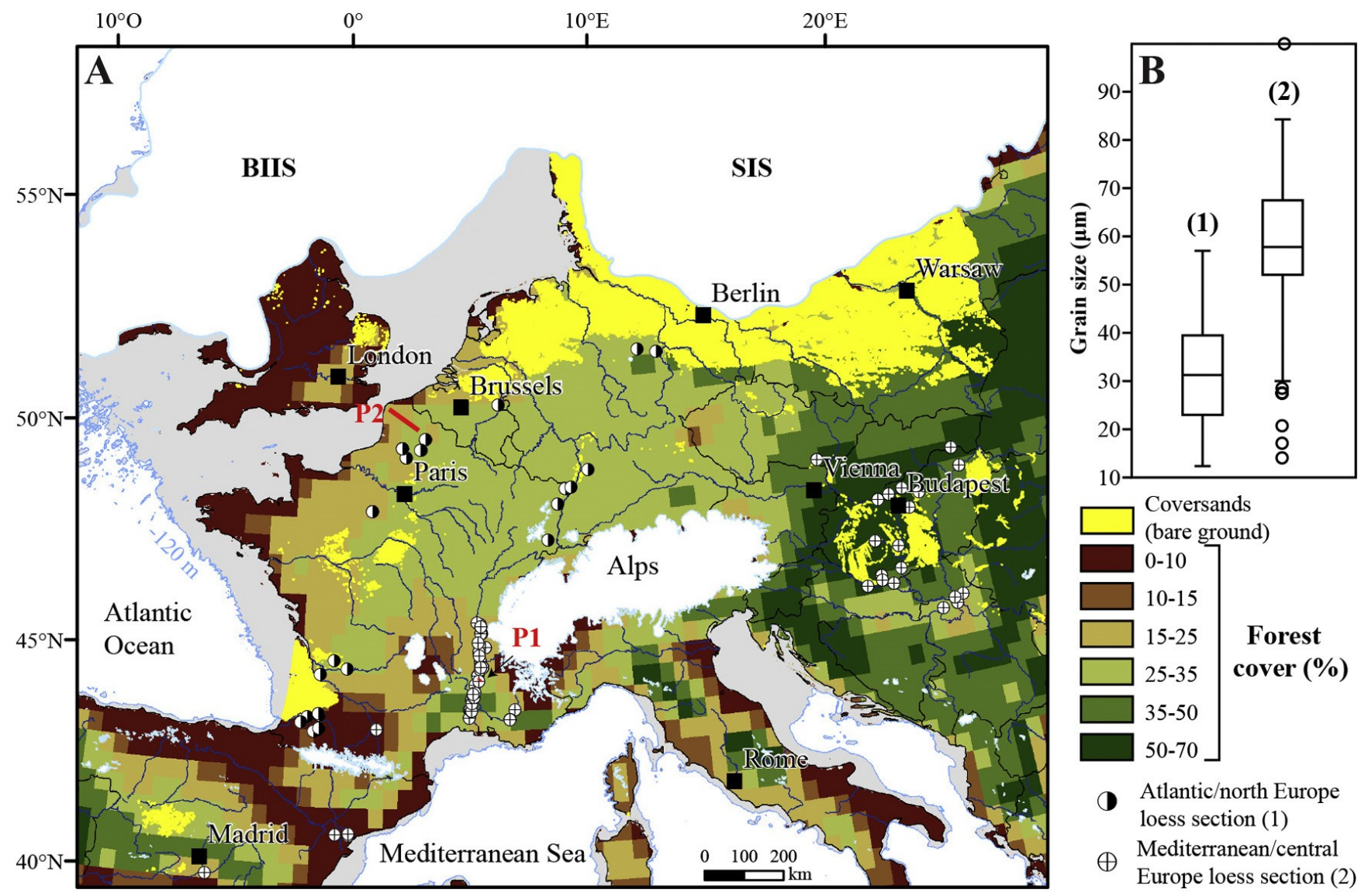

Fig. 12. (A) Proportion of forest cover (needle-leaved trees + broadleaved trees) in Europe during the LGM (after Strandberg et al., 2011). The LGM extent of British-Irish Ice Sheet (BIIS) and Scandinavian Ice Sheet (SIS) is from Hughes et al. (2016), the coversands from Bertran et al. (2016), supplemented by data from Lindner et al. (2017); (B) comparison of the main loess modes from Atlantic/north and Mediterranean/central Europe. The data are from this study and from PANGAEA database (Obreht et al., 2015; Bösken et al., 2016; Krauß et al., 2017; Zeeden et al., 2017a, 2017b) and the literature (Kovács, 2008; Bokhorst et al., 2011; Novothny et al., 2011; Schatz et al., 2011; Varga, 2011; Varga et al., 2012; Vandenberghe et al., 2014; Boixadera et al., 2015; Calvo et al., 2016; Újvári et al., 2016).

\subsection{Age of the aeolian system}

Few chronological data are available to estimate the age of the aeolian system of the Rhône Valley. Radiocarbon and OSL datings indicate that the sand dunes belong to MIS 3-2. The development of slipface dunes in the Rhône Valley during the Last Glacial contrasts with what has been described in the other European aeolian systems during the same period (e.g., NESB, Sable des Landes in southwest France), which were typified by coversand deposition. In those systems, parabolic dunes developed later during the Younger Dryas and the early Holocene (Rendell et al., 1994; Radtke et al., 2001; Kasse, 2002; Koster, 2005; Molodkov and Bitinas, 2006; Tolksdorf and Kaiser, 2012; Sitzia et al., 2015; Zieliński et al., 2015; Kalińska-Nartiša et al., 2016) in connection with landscape colonisation by vegetation (Pye, 1982; Hugenholtz et al., 2008; Pye and Tsoar, 2009). The only known dune examples older than the Younger Dryas come from the Manchega Plain (Spain) with ages between 29 and 19 ka (Bernat Rebollal and Pérez-González, 2008), the Portuguese coast around 20 ka (Costas et al., 2016), and Hungary around 17-15 ka (Borsy et al., 1981; Buró et al., 2016). Early dune formation in southern Europe during the Last Glacial may, therefore, indicate denser vegetation cover in this area than in northern regions. Although scarce, the numerical data indicate that the main period of loess sedimentation in the Rhône Valley occurred during MIS 3-2. This compares well with the data from the other European aeolian 
systems (e.g., Frechen, 2003; Sitzia et al., 2015; Antoine et al., 2016; Lehmkuhl et al., 2016; Zens et al., in press).

However, field evidence (e.g., Bonifay, 1962, 1965) and the development of mature erosional landforms (yardangs, pans) strongly suggest that deflation and aeolian deposition occurred during older periods, probably during most of the middle Pleistocene glacial phases. Many studies have indicated that the formation of yardangs and pans is a slow process that takes several thousand to hundreds of thousands years (e.g., McCauley et al., 1977; Halimov and Fezer, 1989; Washington et al., 2006; Goudie, 2007; Al-Dousari et al., 2009; Sebe et al., 2011; Laity and Bridges, 2013). This suggests that the aeolian system in the study region developed within a long period of time, presumably during several glacial phases of the Pleistocene like other European systems, such as in southwestern France (Sitzia et al., 2015; Bosq et al., in press) and the Danube valley (Marković et al., 2015).

\subsection{Comparison with other upper Pleistocene European aeolian systems}

At the European scale, three types of aeolian systems are distinguished as follows.

\subsubsection{The ice-sheet-controlled north European aeolian system}

The system comprises coversands and loess spreading south of the Scandinavian Ice Sheet (SIS) from northern France to western Russia and referred to as the North European Coversand Belt and Loess Belt (Zeeberg, 1998; Haase et al., 2007; Bertran et al., 2016). The particles derived mainly from the outwash sediments supplied by the ice sheet (Singhvi et al., 2001; Antoine et al., 2009; Smalley et al., 2009; Rousseau et al., 2014). The grain-size distribution shows a gradual transition between coversands, sandy loess, and loess (Koster, 2005; Bertran et al., 2016; Lehmkuhl et al., 2016), similar to the transitional model published by Pye (1995). This grain-size continuum is controlled by the distance to the fluvioglacial sources, the flat topography, and the low and sparse vegetation (tundrasteppe) that did not allow for efficient trapping of the particles (Fig. 12B).

Based on geomorphological data (dunes orientation, ventifacts, grain-size gradients), the efficient winds came mainly from the west and the northwest during MIS 2 (Isarin et al., 1997; Zeeberg, 1998; Renssen et al., 2007). A comparison with modern periglacial environments in west Greenland (Dijkmans and Törnqvist, 1991) led Renssen et al. (2007) to suggest that the efficient winds corresponded mainly to winter winds. In this environment, groundwater table rise during the summer promotes enhanced melting of the glaciers and acts as a limiting factor for deflation. However, Sima et al. (2009) challenged this assumption, as simulations of LGM atmospheric circulation showed that winds from the west mostly occurred during the late winter to the early summer. Winds from the east were also inferred from ventifacts and heavy minerals in Denmark, southern Sweden, and the Eifel region, Germany, and were attributed to katabatic air masses flowing from the SIS (Christiansen and Svensson, 1998; Römer et al., 2016).

\subsubsection{The coastal aeolian systems along the Atlantic Ocean}

Coastal deserts developed along the Atlantic Ocean in Spain, Portugal, and southwest France. They correspond to transgressive dune fields (cf. Hesp, 2013) supplied by the continental shelf exposed to deflation during sea-level lowstands (e.g., Granja et al., 2008; Thomas et al., 2008; Bertran et al., 2011; Costas et al., 2012, 2016; Sitzia et al., 2015, 2017). In southwest France, geochemical analysis indicates that the loess originated mainly from coversand abrasion (Sitzia et al., 2017) and that a gradual transition between sand and loess is observed. The loess belt is poorly developed (southwest 
France) or almost absent (Portugal, Spain). Various factors have been cited to explain the poor development of loess. They include (i) limited dust generation because of sand abrasion (e.g., Smith et al., 1991, 2002; Wright, 2001), (ii) more extensive tree cover than in northern Europe favouring particle entrapment near the sources, and (iii) a moist oceanic climate limiting dust entrainment by the wind.

In southwest France, field proxies suggest that the effective winds came from the westnorthwest during the LGM, implying that deflation was mainly active in spring and summer according to simulations (Sitzia et al., 2017). The deflation season is thought to have been mainly controlled by ground surface conditions, particularly by increased topsoil dryness during the summer in a context of vegetationless coversands.

\subsubsection{The topography-controlled continental aeolian systems}

Pleistocene aeolian systems also developed in inland Europe where the winds were channelled and accelerated by the relief. The aeolian deposits are located along major rivers that were capable of delivering a considerable amount of sand and silt-sized particles (Smalley, 1972). These systems share the following characteristics: (i) an upwind bypass area at the outlet of a corridor, dominated by deflation-related landforms (yardangs, pans, ventifacts); (ii) an accumulation area located downwind, characterized by coversands or dune fields and loess. Such aeolian systems have been described in the Ebro Valley in Spain (Gutiérrez-Elorza et al., 2002; Gutiérrez et al., 2013; Boixadera et al., 2015), the Orb Valley in southern France (Gottis, 1968; Ambert, 1974, 1981, 2013; Ambert and Clauzon, 1992; Carozza et al., 2016), and the Carpathian Basin in Hungary (Ruszkiczay-Rüdiger et al., 2011; Sebe et al., 2011, 2015). The lower Rhône Valley belonged to this type of aeolian system. Because of the southern location, shrub vegetation is thought to have been present in wet grounds along rivers during the LGM. Dust deposition was strongly controlled by vegetation and loess preferentially accumulated in patches near the rivers. Accordingly, the analysis of lipid biomarkers ( $n$-alkanes) in loess sequences from the Balkans by Schatz et al. (2011) and Zech et al. (2013) suggests a significant contribution of deciduous trees and shrubs.

\section{Conclusion}

The Rhône Valley is an aeolian system characterized by strong unidirectional winds channelled by the relief, intense deflation, and a major river draining the alpine ice cap and parallel to the prevailing winds, able to deliver large amounts of easily remobilisable sedimentary material. This aeolian system differs in many ways from the North European Coversand Belt and Loess Belt and from the coastal systems but closely resembles the continental systems such as the Carpathian.

The map of aeolian deposits derived from the LUCAS topsoil database gives a more comprehensive picture of their distribution in southeast France than the previously available maps based on a conventional geological approach. Comparison between the new map and the distribution of known cross sections shows a good fit at the scale of the study area. The new map also highlights the control played by the Rhône River on the distribution of sand and loess and strongly suggests that alluvial bars and the floodplain were the main sources of particles during the glacial. Overall, the aeolian system comprised two main components as follows:

- A bypass area downstream from valley narrowings near latitude $45^{\circ} \mathrm{N}$, which promoted wind channelling and acceleration. Deflation-related landforms prevailed in this area. Wind deceleration near topographic obstacles allowed for sand deposition on the windward and leeward slopes, thus forming sand ramps.

- Areas of net accumulation developed in the periphery, and probably on the now submerged continental plateau. The persistence of shrub vegetation in moist grounds along the valleys during the LGM is assumed to have played a major role in loess deposition. Vegetation enabled trapping of 
sand and coarse silt particles transported by saltation and short-term suspension close to the sources, thus accumulating dominantly coarse loess.

As mentioned above, the depositional history of the aeolian deposits in southeast France remains poorly documented and should prompt new investigations using OSL and radiocarbon dating. Because the accumulation rate is controlled by global climate forcings and local factors such as the availability of easily remobilisable particles and ground surface conditions. Therefore, we expect that the chronology of this aeolian system will not perfectly fit that of more northern European systems like the NELB. Geochemical and mineralogical analyses will also provide more insight into the origin of the particles.

\section{Acknowledgements}

This research was conducted with the financial support of the LaScArBx (research program of the Agence Nationale de la Recherche ANR-10-LABX-52), and involving the University of Bordeaux, the PACEA laboratory, and the Institut National de Recherches Archologiques Préventives (Inrap). We furthermore thank all of the people who sent loess samples for grain-size analysis, P. Antoine, J.-L. Brochier, O. Franc, M. Liard, O. Moine, L. Sitzia, J. Vandenberghe, P. Wuscher. Many thanks to M.-P. Bataille for the sieve-pipette grain-size analysis, F. Santos for his help in using the R software, J.-L. Brochier for sharing his knowledge on the study region, H. Tissoux for providing the digitalised BRGM 1:50,000 geological map, G. Strandberg for providing the simulated LGM vegetation cover, and $\mathrm{M}$. Corbé for field assistance. The people who provided us with access to archaeological excavations, E. Morin, C. Ronco, M. Rué and J.-M. Lepape, are also warmly acknowledged.

We are grateful to the three anonymous reviewers and the editor for constructive comments and suggestions.

\section{References}

Adelsberger, K.A., Smith, J.R., 2009. Desert pavement development and landscape stability on the Eastern Libyan Plateau, Egypt. Geomorphology 107, 178-194.

Aishan, T., Halik, Ü., Cyffka, B., Kuba, M., Abliz, A., Baidourela, A., 2013. Monitoring the hydrological and ecological response to water diversion in the lower reaches of the Tarim River, Northwest China. Quat. Int. 311, 155-162.

Al-Dousari, A.M., Al-Elaj, M., Al-Enezi, E., Al-Shareeda, A., 2009. Origin and characteristics of yardangs in the Um Al-Rimam depressions (N Kuwait). Geomorphology 104, 93-104.

Alimen, H., 1965. Pétrographie des limons de Provence. Bull. Assoc. Fr. Étud. Quat. 2, 35-65.

Ambert, P., 1973. Géomorphologie de l'Etang de Berre et de ses bordures. (Ph.D. Thesis). Université d'Aix-Marseille 2, Aix-en-Provence.

Ambert, P., 1974. Les dépressions nivéo-éoliennes de Basse Provence. C. R. Acad. Sci. Sér. D 279, 727-729.

Ambert, P., 1981. L'âge de l'érosion éolienne en Languedoc et en Provence. C. R. Acad. Sci. Ser. II 293, 783-786.

Ambert, P., 2013. Formes et formations périglaciaires du Pléistocène supérieur dans le Midi méditerranéen français: l'exemple de l'Étang de Berre. Quaternaire 24, 293-301.

Ambert, P., Clauzon, G., 1992. Morphogenèse éolienne en ambiance périglaciaire: les dépressions fermées du pourtour du Golfe du Lion (France méditerranéenne). Z. Geomorphol. Suppl. 84, 5571.

Amit, R., Enzel, Y., Crouvi, O., Simhai, O., Matmon, A., Porat, N., McDonald, E., Gillespie, A.R., 2011. The role of the Nile in initiating a massive dust influx to the Negev late in the middle Pleistocene. Geol. Soc. Am. Bull. 123, 873-889. 
Andrieux, E., Bertran, P., Antoine, P., Deschodt, L., Lenoble, A., Coutard, S., Ajas, A., Borderie, Q., Coutard, J.-P., Didierjean, F., Dousteyssier, B., Ferrier, C., Gardère, P., Gé, T., Liard, M., Locht, J., Naton, H., Rue, M., Sitzia, L., Vliet-Lanoe, B.V., Vernet, G., 2016a. Database of pleistocene periglacial features in France: description of the online version. Quaternaire 27, 329-339.

Andrieux, E., Bertran, P., Saito, K., 2016b. Spatial analysis of the French Pleistocene permafrost by a GIS database. Permafr. Periglac. Process. 27, 17-30.

Antoine, P., Rousseau, D.-D., Moine, O., Kunesch, S., Hatté, C., Lang, A., Tissoux, H., Zöller, L., 2009. Rapid and cyclic aeolian deposition during the Last Glacial in European loess: a high-resolution record from Nussloch, Germany. Quat. Sci. Rev. 28, 2955-2973.

Antoine, P., Rousseau, D.-D., Degeai, J.-P., Moine, O., Lagroix, F., Kreutzer, S., Fuchs, M., Hatté, C., Gauthier, C., Svoboda, J., Lisá, L., 2013. High-resolution record of the environmental response to climatic variations during the Last Interglacial-Glacial cycle in Central Europe: the loess-palaeosol sequence of Dolní Věstonice (Czech Republic). Quat. Sci. Rev. 67, 17-38.

Antoine, P., Coutard, S., Guerin, G., Deschodt, L., Goval, E., Locht, J.-L., Paris, C., 2016. Upper Pleistocene loess-palaeosol records from Northern France in the European context: environmental background and dating of the Middle Palaeolithic. Quat. Int. 411, 4-24.

Arnal, H., 1971a. Phénomènes périglaciaires dans la basse vallée du Rhône. Formations quaternaires du rebord sud et alluvions du fond de l'étang de Pujaut. Bull. Assoc. Fr. Étud. Quat. 8, 145-149.

Arnal, H., 1971b. Les sols polygonaux étirés et sols striés d'âge würmien de Landun (Gard). Bull. Assoc. Fr. Étud. Quat. 8, 151-160.

Arpe, K., Leroy, S.A.G., Mikolajewicz, U., 2011. A comparison of climate simulations for the last glacial maximum with three different versions of the ECHAM model and implications for summer-green tree refugia. Clim. Past 7, 91-114.

Ashley, G.M., 1978. Interpretation of polymodal sediments. J. Geol. 86, 411-421.

Bagnold, R.A., Barndorff-Nielsen, O., 1980. The pattern of natural size distributions. Sedimentology 27, 199-207.

Ballabio, C., Panagos, P., Montanarella, L., 2016. Mapping topsoil physical properties at European scale using the LUCAS database. Geoderma 261, 110-123.

Ballais, J.-L., Riser, J., 1996. La terrasse du Plan de Dieu: un épandage de piémont. Études Vauclusiennes 55, 17-23.

Bassetti, M.A., Jouet, G., Dufois, F., Berné, S., Rabineau, M., Taviani, M., 2006. Sand bodies at the shelf edge in the Gulf of Lions (Western Mediterranean): deglacial history and modern processes. Mar. Geol. 234, 93-109.

Bateman, M.D., Bryant, R.G., Foster, I.D.L., Livingstone, I., Parsons, A.J., 2012. On the formation of sand ramps: a case study from the Mojave Desert. Geomorphology 161-162, 93-109.

Bazile, F., 2007. Le Gravettien de la France méditerranéenne. PALEO 19, 89-103.

Beaudouin, C., Jouet, G., Suc, J.-P., Berné, S., Escarguel, G., 2007. Vegetation dynamics in southern France during the last $30 \mathrm{ky} \mathrm{BP}$ in the light of marine palynology. Quat. Sci. Rev. 26, 1037-1054.

Beaulieu, J.-L., Miras, Y., Andrieu-Ponel, V., Guiter, F., 2005. Vegetation dynamics in northwestern Mediterranean regions: instability of the Mediterranean bioclimate. Plant Biosyst. 139, 114-126.

Beeching, A., Brochier, J.-L., Cordier, F., Baudais, D., Hénon, P., Jallet, F., Treffort, J.-M., Raynaud, K., 2006. Montélimar-Le Gournier: historique des recherches et présentation d'un "grand site" de plaine. Actes des 7èmes Rencontres Méridionales de Préhistoire Récente. Maison de l'Orient et de la Méditerranée, Bron, France, pp. 187-205. 
Ben-Israel, M., Enzel, Y., Amit, R., Erel, Y., 2015. Provenance of the various grain-size fractions in the Negev loess and potential changes in major dust sources to the eastern Mediterranean. Quat. Res. 83, 105-115.

Bernat Rebollal, M., Pérez-González, A., 2008. Inland aeolian deposits of the Iberian Peninsula: sand dunes and clay dunes of the Duero Basin and the Manchega Plain. Palaeoclimatic considerations. Geomorphology 102, 207-220.

Bertram, S., 2003. Late Quaternary Sand Ramps in South-western Namibia. (Ph.D Thesis). Würzburg University, Germany.

Bertran, P., Bateman, M.D., Hernandez, M., Mercier, N., Millet, D., Sitzia, L., Tastet, J.-P., 2011. Inland aeolian deposits of south-west France: facies, stratigraphy and chronology. J. Quat. Sci. 26, 374388.

Bertran, P., Sitzia, L., Banks, W.E., Bateman, M.D., Demars, P.-Y., Hernandez, M., Lenoir, M., Mercier, N., Prodeo, F., 2013. The Landes de Gascogne (southwest France): periglacial desert and cultural frontier during the Palaeolithic. J. Archaeol. Sci. 40, 2274-2285.

Bertran, P., Liard, M., Sitzia, L., Tissoux, H., 2016. A map of Pleistocene aeolian deposits in Western Europe, with special emphasis on France. J. Quat. Sci. 31, 844-856.

Boixadera, J., Poch, R.M., Lowick, S.E., Balasch, J.C., 2015. Loess and soils in the eastern Ebro Basin. Quat. Int. 376, 114-133.

Bokhorst, M.P., Vandenberghe, J., Sümegi, P., Łanczont, M., Gerasimenko, N.P., Matviishina, Z.N., Marković, S.B., Frechen, M., 2011. Atmospheric circulation patterns in central and eastern Europe during the Weichselian Pleniglacial inferred from loess grainsize records. Quat. Int. 234, 62-74.

Bonifay, E., 1962. Les Terrains quaternaires dans le Sud-Est de la France. Delmas, Bordeaux. Bonifay, E., 1965. Stratigraphie des loess anciens et récents dans le sud-est de la France. Bull. Assoc. Fr. Étud. Quat. 2, 21-34.

Borsy, Z., Csongor, É., Sárkány, S., Szabó, I., 1981. Phases of blown-sand movements in the north-east part of the Great Hungarian Plain. Acta Geogr. Ac Geol. Meteorol. Debrecina 20, 5-33.

Bösken, J., Zeeden, C., Hambach, U., Obreht, I., Lehmkuhl, F., 2016. Profile characteristics of the last glacial Gravettian site "Ságvár Lyukas Hill" (Hungary). PANGAEA https://doi.org/

10.1594/PANGAEA.868368 (Supplement to: Bösken, J., Sümegi, P., Zeeden, C., Klasen, N., Gulyás, S., Lehmkuhl F., 2017: Investig. Last Glacial Gravettian Site "Ságvár Lyukas Hill” (Hungary) and its paleoenvironmental and geochronological context using a multi-proxy approach. Palaeogeogr. Palaeoclimatol. Palaeoecol. https://doi.org/ 10.1594/PANGAEA.868368).

Bosq, M., Bertran, P., Beauval, C., Kreutzer, S., Duval, M., Bartz, M., Mercier, N., Sitzia, L., 2018. Stratigraphy and chronology of Pleistocene coastal deposits in northern Aquitaine, France: a reinvestigation. Quaternaire (in press).

Bourdier, F., 1961. Le bassin du Rhône au Quaternaire: géologie et préhistoire. CNRS, Paris.

Bouteyre, G., Allemann, M., 1964. Sur quelques phénomènes périglaciaires en Costières du Gard: un réseau polygonal de fentes en coin. Bull. Soc. Sci. Nat. Nîmes 50, 3-15.

Brochier, J., Livache, M., 1978. Le niveau C de l'abri n 1 de Chinchon à Saumanes de Vaucluse: analyse des correspondances et ses conséquences quant à l'origine des complexes du Tardiglaciaire en Vaucluse. Géol. Méditerr. 5, 359-369.

Bronger, A., Heinkele, T., 1990. Mineralogical and clay mineralogical aspects of loess research. Quat. Int. 7-8, 37-51. 
Bullard, J.E., Austin, M.J., 2011. Dust generation on a proglacial floodplain, West Greenland. Aeolian Res. 3, 43-54.

Buoncristiani, J.-F., Campy, M., 2011. Quaternary glaciations in the French Alps and Jura. In: Ehlers, J., Gibbard, P.L., Hughes, P.D. (Eds.), Quaternary Glaciations - Extent and Chronology: A Closer Look, Developments in Quaternary Science. Elsevier, Amsterdam, pp. 117-126.

Buró, B., Sipos, G., Lóki, J., Andrási, B., Félegyházi, E., Négyesi, G., 2016. Assessing Late Pleistocene and Holocene phases of aeolian activity on the Nyírség alluvial fan, Hungary. Quat. Int. 425, 183 195.

Cailleux, A., Rousset, C., 1968. Présence de réseaux polygonaux de fentes en coin en BasseProvence occidentale et leur signification paléoclimatique. C. R. Acad. Sci. Paris 266, 669-671.

Calvo, F.R., Sánchez, J., Acosta, A., Wolf, D., Faust, D., 2016. Granulometrical, mineralogical and geochemical characterization of loess deposits in the Tajo Basin. Quat. Int. 407, 14-28.

Carozza, J.-M., Llubes, M., Danu, M., Faure, E., Carozza, L., David, M., Manen, C., 2016. Geomorphological evolution of Mediterranean enclosed depressions in the late glacial and Holocene: the example of Canohès (Roussillon, SE France). Geomorphology 273, 78-92.

Catt, J.A., 2001. The agricultural importance of loess. Earth-Sci. Rev. 54, 213-229.

Cazalis De Fondouce, P., 1879. Érosion de cailloux quaternaires dus à l'action du vent et du sable. Association Française pour l'Avancement des Sciences, Montpellier, pp. 646-650.

Chardon, M., 1975. L'évolution morphologique des régions à l'Ouest du Rhône entre l'Ardoise et Aramon. Le réseau hydrographique et son évolution au Quaternaire. Versants et cuvettes de la dépression de Pujaut. Rev. Geogr. Alp. 63, 313-328.

Cheddadi, R., Vendramin, G.G., Litt, T., Francois, L., Kageyama, M., Lorentz, S., Laurent, J.-M., de Beaulieu, J.-L., Sadori, L., Jost, A., Lunt, D., 2006. Imprints of glacial refugia in the modern genetic diversity of Pinus sylvestris. Glob. Ecol. Biogeogr. 15, 271-282.

Christiansen, H.H., 2004. Windpolished boulders and bedrock in the Scottish Highlands:

evidence and implications of Late Devensian wind activity. Boreas 33, 82-94.

Christiansen, H.H., Svensson, H., 1998. Windpolished boulders as indicators of a late Weichselian wind regime in Denmark in relation to neighbouring areas. Permafr. Periglac. Process. 9, 1-21.

Clauzon, G., 1982. Le canyon messinien du Rhône; une preuve decisive du "desiccated deep-basin model" (Hsue, Cita and Ryan, 1973). Bull. Soc. Geol. Fr. 7, 597-610.

Clauzon, G., Ambert, P., Vaudour, J., 1990. Cartographie géomorphologique de la BasseProvence rhodanienne. Méditerranée 71, 75-82.

Clauzon, G., Suc, J.-P., Gautier, F., Berger, A., Loutre, M.-F., 1996. Alternate interpretation of the Messinian salinity crisis: controversy resolved? Geology 24, 363-366.

Colomb, E., Servais, J., L'Homer, A., Masse, J., Rousset, C., Roux, R., Rouire, J., Damiani, L., Durozoy, G., 1977. Notice explicative de la carte géologique d'Eyguières au 1/50000. BRGM, Orléans.

Costas, S., Jerez, S., Trigo, R.M., Goble, R., Rebêlo, L., 2012. Sand invasion along the Portuguese coast forced by westerly shifts during cold climate events. Quat. Sci. Rev. 42, 15-28.

Costas, S., Naughton, F., Goble, R., Renssen, H., 2016. Windiness spells in SW Europe since the last glacial maximum. Earth Planet. Sci. Lett. 436, 82-92.

Coudé-Gaussen, G., 1990. The loess and loess-like deposits along the sides of the western Mediterranean Sea: genetic and palaeoclimatic significance. Quat. Int. 5, 1-8. 
Coutterand, S., 2010. Etude géomorphologique des flux glaciaires dans les Alpes nordoccidentales au Pléistocène récent: du maximum de la dernière glaciation aux premières étapes de la déglaciation. (Ph.D Thesis). Université de Savoie, Chambéry.

Crouvi, O., Amit, R., Enzel, Y., Porat, N., Sandler, A., 2008. Sand dunes as a major proximal dust source for late Pleistocene loess in the Negev Desert, Israel. Quat. Res. 70, 275-282.

Damiani, L., Masse, J., Philip, J., Tronchetti, G., Triat, J., Truc, G., Vogt, J., Bazile, F., 1980. Notice explicative de la carte géologique de Pont-Saint-Esprit au 1/50000. BRGM, Orléans.

Danin, A., Ganor, E., 1991. Trapping of airborne dust by mosses in the Negev Desert, Israel. Earth Surf. Process. Landf. 16, 153-162.

Danin, A., Yaalon, D.H., 1981. Trapping of silt by lichens and mosses in the desert environment of the Dead Sea region, Israel. International Conference on Aridic Soils, p. 29 (Jérusalem).

Debard, E., 1987. L'apport allochtone éolien dans les remplissages karstiques quaternaires du BasVivarais (S.E. France). Bull. Assoc. Fr. Étud. Quat. 24, 183-193.

Debard, E., 1988. Le quaternairedu Bas-Vivarais d'après l'étude des remplissages d'avens, de porches de grottes et d'abris sous roche: dynamique sédimentaire, paléoclimatologie et chronologie. Doc. Lab. Géol., Lyon.

Dèzes, P., Schmid, S.M., Ziegler, P.A., 2004. Evolution of the European Cenozoic Rift System: interaction of the Alpineand Pyrenean orogens with their forelandlithosphere. Tectonophysics 389, 1-33.

Dijkmans, J.W.A., Törnqvist, T.E., 1991. Modern periglacial eolian deposits and landforms in the Søndre Strømfjord area, West Greenland and their palaeoenvironmental implications. Medd. Grønl. Geosci. 25, 3-39.

Dubar, M., 1972. Stratigraphie des formations plio-pléistocènes de la région de Puimoisson-SaintJurs-Segries (Alpes-de-Haute-Provence). Bull. Assoc. Fr. Étud. Quat. 9, 185-194.

Dubar, M., 1979. I.-Les caractères sédimentologiques des terrasses fluviatiles et leur couverture limoneuse en Moyenne Durance. Bull. Assoc. Fr. Étud. Quat. 16, 109-120.

Dubar, M., 1983. Stratigraphie des dépôts du Néogène Supérieur et du Pléistocène du bassin de la moyenne Durance. Interprétations géodynamiques et paléogéographiques. (Ph.D. Thesis). Université de Provence, Marseille, France.

Durcan, J.A., King, G.E., Duller, G.A.T., 2015. DRAC: Dose Rate and Age Calculator for trapped charge dating. Quat. Geochronol. 28, 54-61.

Ehlers, J., Gibbard, P.L., 2004. Quaternary Glaciations-Extent and Chronology: Part I: Europe. Elsevier, Amsterdam.

Enzel, Y., Amit, R., Crouvi, O., Porat, N., 2010. Abrasion-derived sediments under intensified winds at the latest Pleistocene leading edge of the advancing Sinai-Negev erg. Quat. Res. 74, 121-131.

Field, J.P., Breshears, D.D., Whicker, J.J., Zou, C.B., 2012. Sediment capture by vegetation patches: implications for desertification and increased resource redistribution. J. Geophys. Res. Biogeosci. 117.

Fisher, P., Aumann, C., Chia, K., O'Halloran, N., Chandra, S., 2017. Adequacy of laser diffraction for soil particle size analysis. PLoS One 12, e0176510.

Franc, O., Moine, O., Fülling, A., Auguste, P., Pasty, J.-F., Gadiolet, P., Gaertner, V., Robert, V., 2017. Les séquences alluvio-loessique du Würm moyen/supérieur de Quincieux et de Lyon (Rhône-Alpes, France): premières intérprétation paléoenvironnementales et corrélations. Quaternaire $28,423-$ 454. 
Frechen, M., 2003. Loess in Europe-mass accumulation rates during the Last Glacial Period. Quat. Sci. Rev. 22, 1835-1857.

Gabert, J., 1965. Phénomènes périglaciaires du Quaternaire supérieur et néotectonique dans la région de l'Étang de Berre (Basse-Provence occidentale). 90ème Congrès des Sociétés Savantes, Nice 2, pp. 75-88.

Gabert-Delay, J., 1967. L'importance des déformations quaternaires et du modelé cryonival wûrmien dans les paysages du bas Rhône et de la basse Durance. Méditerranée 8, 87-107.

González-Sampériz, P., Valero-Garcés, B.L., Carrión, J.S., Peña-Monné, J.L., García-Ruiz, J.M., MartíBono, C., 2005. Glacial and Lateglacial vegetation in northeastern Spain: new data and a review. Quat. Int. 140-141, 4-20.

González-Sampériz, P., Valero-Garcés, B.L., Moreno, A., Morellón, M., Navas, A., Machín, J., DelgadoHuertas, A., 2008. Vegetation changes and hydrological fluctuations in the Central Ebro Basin (NE Spain) since the Late Glacial period: saline lake records. Palaeogeogr. Palaeoclimatol. Palaeoecol. 259, 157-181.

Gottis, M., 1968. Les dépressions fermées du Languedoc: Hypothèses sur leur mode de formation. Actes Soc. Linn. Bordeaux 105, 1-5.

Goudie, A.S., 2007. Mega-yardangs: a global analysis. Geogr. Compass 1, 65-81.

Goudie, A.S., 2013. Arid and Semi-arid Geomorphology. Cambridge University Press, Cambridge.

Granja, H.M., Dte Groot, T.A.M., Costa, A.L., 2008. Evidence for Pleistocene wet aeolian dune and interdune accumulation, S. Pedro da Maceda, north-west Portugal: evidence for Pleistocene wet aeolian dune. Sedimentology 55, 1203-1226.

Gutiérrez, F., Valero-Garcés, B., Desir, G., González-Sampériz, P., Gutiérrez, M., Linares, R., Zarroca, M., Moreno, A., Guerrero, J., Roqué, C., Arnold, L.J., Demuro, M., 2013. Late Holocene evolution of playa lakes in the central Ebro depression based on geophysical surveys and morpho-stratigraphic analysis of lacustrine terraces. Geomorphology 196, 177-197.

Gutiérrez-Elorza, M., Desir, G., Gutiérrez-Santolalla, F., 2002. Yardangs in the semiarid central sector of the Ebro Depression (NE Spain). Geomorphology 44, 155-170.

Györgyövics, K., Kiss, T., 2013. Dune hierarchy and morphometric classes of the parabolic sand dune association of Inner Somogy, Hungary. Studia Geomorphologica CarpathoBalcanica 47, 31-48.

Haase, D., Fink, J., Haase, G., Ruske, R., Pécsi, M., Richter, H., Altermann, M., Jäger, K.-D., 2007. Loess in Europe-its spatial distribution based on a European Loess Map, scale 1:2,500,000. Quat. Sci. Rev. 26, 1301-1312.

Haesaerts, P., Damblon, F., Gerasimenko, N., Spagna, P., Pirson, S., 2016. The Late Pleistocene loesspalaeosol sequence of Middle Belgium. Quat. Int. 411, 25-43.

Halimov, M., Fezer, F., 1989. 8 yardang types in Central-Asia. Z. Geomorphol. 33, 205-217. Hedin, S., 1903. Central Asia and Tibet. Hurst and Blackett, London.

Hesp, P., 2013. Conceptual models of the evolution of transgressive dune field systems. Geomorphology 199, 138-149.

Hoffmann, C., Funk, R., Wieland, R., Li, Y., Sommer, M., 2008. Effects of grazing and topography on dust flux and deposition in the Xilingele grassland, Inner Mongolia. J. Arid Environ. 72, 792-807. Hopcroft, P.O., Valdes, P.J., Woodward, S., Joshi, M.M., 2015. Last glacial maximum radiative forcing from mineral dust aerosols in an earth system model. J. Geophys. Res. Atmos. 120, 8186-8205. 
Hörner, N.G., 1932. Lop-nor.Topographical and geologicalsummary.Geogr. Ann.14,297-321. Hsü, K.J., Ryan, W.B.F., Cita, M.B., 1973. Late Miocene desiccation of the Mediterranean. Nature 242, 240244.

Hugenholtz, C.H., Wolfe, S.A., 2010. Rates and environmental controls of aeolian dust accumulation, Athabasca River Valley, Canadian Rocky Mountains. Geomorphology 121, 274-282.

Hugenholtz, C.H., Wolfe, S.A., Moorman, B.J., 2008. Effects of sand supply on the morphodynamics and stratigraphy of active parabolic dunes, Bigstick Sand Hills, southwestern Saskatchewan. Can. J. Earth Sci. 45, 321-335.

Hughes, A.L., Gyllencreutz, R., Lohne, Ø.S., Mangerud, J., Svendsen, J.I., 2016. The last Eurasian ice sheets-a chronological database and time-slice reconstruction, DATED-1. Boreas 45, 1-45.

Hunter, R.E., 1977. Basic types of stratification in small eolian dunes. Sedimentology 24, 361-387. Huntley, D.J., Godfrey-Smith, D.I., Thewalt, M.L.W., 1985. Optical dating of sediments. Nature 313, 105-107.

Isarin, R.F.B., Renssen, H., Koster, E.A., 1997. Surface wind climate during the Younger Dryas in Europe as inferred from aeolian records and model simulations. Palaeogeogr. Palaeoclimatol. Palaeoecol. 134, 127-148.

ISO, 2009. Particle Size Analysis - Laser Diffraction Methods, Part 1: General Principles, Annex A: Theoretical Background of Laser Diffraction. ISO 13320. International Organization for Standardization, Geneva.

Ivy-Ochs, S., Kerschner, H., Reuther, A., Preusser, F., Heine, K., Maisch, M., Kubik, P., Schlüchter, C., 2008. Chronology of the last glacial cycle in the European Alps. J. Quat. Sci. 23, 559-573.

Jacq, V., Albert, P., Delorme, R., 2005. Le mistral, en 1925 et aujourd'hui: Le mistralQuelques aspects des connaissances actuelles. La Météorologie 30-38.

Jiang, Q., Smith, R.B., Doyle, J., 2003. The nature of the mistral: observations and modelling of two MAP events. Q. J. R. Meteorol. Soc. 129, 857-875.

Joly, D., Brossard, T., Cardot, H., Cavailhes, J., Hilal, M., Wavresky, P., 2010. Les types de climats en France, une construction spatiale. Cybergeo https://doi.org/10.4000/cybergeo.23155.

Jones, R.M., 2003. Particle size analysis by laser diffraction: ISO 13320, standard operating procedures, and Mie theory. Am. Lab. 35, 44-47.

Jorda, M., Rosique, T., Évin, J., 2000. Données nouvelles sur l'âge du dernier maximum glaciaire dans les Alpes méridionales françaises. C. R. Acad. Sci., Paris, Earth Planet. Sci. 331, 187-193.

Jouet, G., Berné, S., Rabineau, M., Bassetti, M.A., Bernier, P., Dennielou, B., Sierro, F.J., Flores, J.A., Taviani, M., 2006. Shoreface migrations at the shelf edge and sea-level changes around the Last Glacial Maximum (Gulf of Lions, NW Mediterranean). Mar. Geol. 234, 21-42.

Kalińska-Nartiša, E., Thiel, C., Nartišs, M., Buylaert, J.-P., Murray, A.S., 2016. The northeastern aeolian 'European Sand Belt' as potential record of environmental changes:

a case study from Eastern Latvia and Southern Estonia. Aeolian Res. 22, 59-72.

Kasse, C., 1997. Cold-climate aeolian sand-sheet formation in north-western Europe (c. 14-12.4 ka); a response to permafrost degradation and increased aridity. Permafr. Periglac. Process. 8, 295-311.

Kasse, C., 2002. Sandy aeolian deposits and environments and their relation to climate during the Last Glacial Maximum and Lateglacial in northwest and central Europe. Prog. Phys. Geogr. 26, 507532.

Knight, J., 2008. The environmental significance of ventifacts: a critical review. Earth-Sci. Rev. 86, 89105. 
Kocurek, G., Dott Jr., R.H., 1981. Distinctions and uses of stratification types in the interpretation of eolian sand. J. Sediment. Res. 51.

Kocurek, G., Havholm, K.G., 1993. Eolian sequence stratigraphy-a conceptual framework. In: Weimer, P., Posamentier, H. (Eds.), Recent Advances in and Applications of Siliciclastic Sequence Stratigraphy. American Association of Petroleum Geologists Memoir 58, pp. 393-409 (Tulsa).

Kocurek, G., Nielson, J., 1986. Conditions favourable for the formation of warm-climate aeolian sand sheets. Sedimentology 33, 795-816.

Kok, J.F., Parteli, E.J., Michaels, T.I., Karam, D.B., 2012. The physics of wind-blown sand and dust. Rep. Prog. Phys. 75, 106901.

Konert, M., Vandenberghe, J.E.F., 1997. Comparison of laser grain size analysis with pipette and sieve analysis: a solution for the underestimation of the clay fraction.

Sedimentology 44, 523-535.

Koster, E.A., 2005. Recent advances in luminescence dating of Late Pleistocene (coldclimate) aeolian sand and loess deposits in western Europe. Permafr. Periglac. Process. 16, 131-143.

Kovács, J., 2008. Grain-size analysis of the Neogene red clay formation in the Pannonian Basin. Int. J. Earth Sci. 97, 171-178.

Kovács, J., Fábián, S.Á., Varga, G., Újvári, G., Varga, G., Dezső, J., 2011. Plio-Pleistocene red clay deposits in the Pannonian basin: a review. Quat. Int. 240, 35-43.

Krauß, L., Zens, J., Zeeden, C., Schulte, P., Eckmeier, E., Lehmkuhl, F., 2016. A multi-proxy analysis of two loess-paleosol sequences in the Northern Harz Foreland, Germany. Palaeogeogr.

Palaeoclimatol. Palaeoecol. 461, 401-417.

Krauß, L., Zens, J., Zeeden, C., Schulte, P., Eckmeier, E., Lehmkuhl, F., 2017. Multi-proxy analysis of two loess-paleosol sequences in the northern Harz Foreland, Germany. PANGAEA https://doi.org/10.1594/PANGAEA.870512 (Supplement to: Krauß, L. et al. (2016): A Multi-Proxy Analysis of two Loess-Paleosol Sequences in the Northern Harz Foreland, Germany. Palaeogeogr. Palaeoclimatol. Palaeoecol. 461 401-417, https://doi.org/10.1016/j.palaeo.2016.09.001).

Kreutzer, S., Schmidt, C., Fuchs, M.C., Dietze, M., Fischer, M., Fuchs, M., 2012. Introducing an R package for luminescence dating analysis. Ancient TL 30 (1), 1-8.

Kreutzer, S., Dietze, M., Burow, C., Fuchs, M.C., Schmidt, C., Fischer, M., Friedrich, J., 2018. Luminescence: comprehensive luminescence dating data analysis. CRAN version 0.8.2. https://CRAN.R-project.org/package=Luminescence.

Kuba, M., Aishan, T., Cyffka, B., Halik, U., 2013. Analysis of connections between soil moisture, groundwater level and vegetation vitality along two transects at the lower reaches of the Tarim River, Northwest China. Geo-Öko 34, 103-128.

Kumar, A., Srivastava, P., Meena, N.K., 2017. Late Pleistocene aeolian activity in the cold desert of Ladakh: a record from sand ramps. Quat. Int. 443, 13-28.

Lacquement, F., Prognon, F., Prognon, C., Courbouleix, S., Quesnel, F., Karnay, G., Thomas, E., 2010. Etat des lieux de la connaissance cartographie du régolithe (Rapport final No. BRGM/RP-57932FR). BRGM, Orléans.

Laity, J.E., 1994. Landforms of aeolian erosion. In: Abrahams, A.D., Parsons, A.J. (Eds.), Geomorphology of Desert Environments. Chapman \& Hall, London, pp. 506-535.

Laity, J.E., 2009. Landforms, landscapes, and processes of aeolian erosion. In: Parsons, A.J., Abrahams, A.D. (Eds.), Geomorphology of Desert Environments. Springer, Berlin, pp. 597-627. 
Abraded systems. In: Laity, J.E., Bridges, N.T., Schroder, J., Lancaster, N., Sherman, D.J., Baas (Eds.), Treatise on Geomorphology. Academic Press, San Diego, pp. 269-286.

Lancaster, N., Baas, A., 1998. Influence of vegetation cover on sand transport by wind:

field studies at Owens Lake, California. Earth Surf. Process. Landf. 23, 69-82.

Lancaster, N., Tchakerian, V.P., 1996. Geomorphology and sediments of sand ramps in the Mojave Desert. Geomorphology 17, 151-165.

Lautridou, J.-P., 1984. Le cycle périglaciaire pléistocène en Europe du Nord-Ouest et plus particulièrement en Normandie. (Ph.D. Thesis). Université de Caen, France.

Leenders, J.K., van Boxel, J.H., Sterk, G., 2007. The effect of single vegetation elements on wind speed and sediment transport in the Sahelian zone of Burkina Faso. Earth Surf. Process. Landf. 32, 14541474.

Lehmkuhl, F., Zens, J., Krauß, L., Schulte, P., Kels, H., 2016. Loess-paleosol sequences at the northern European loess belt in Germany: distribution, geomorphology and stratigraphy. Quat. Sci. Rev. 153, 11-30.

L'Homer, A., Colomb, E., Gieu, G., Masse, J., Rouire, J., Roux, M., 1975. Notice explicative de la carte géologique d'Istres au 1/50000. BRGM, Orléans.

Lim, J., Matsumoto, E., 2006. Bimodal grain-size distribution of aeolian quartz in a maar of Cheju Island, Korea, during the last 6500 years: its flux variation and controlling factor. Geophys. Res. Lett. 33, L21816.

Lin, L.I.-K., 1989. A concordance correlation coefficient to evaluate reproducibility. Biometrics 45 , 255.

Lin, L., Hedayat, A.S., Sinha, B., Yang, M., 2002. Statistical methods in assessing agreement: models, issues, and tools. J. Am. Stat. Assoc. 97, 257-270.

Lin, Y., Mu, G., Xu, L., Zhao, X., 2016. The origin of bimodal grain-size distribution for aeolian deposits. Aeolian Res. 20, 80-88.

Lindner, H., Lehmkuhl, F., Zeeden, C., 2017. Spatial loess distribution in the eastern Carpathian Basin: a novel approach based on geoscientific maps and data. J. Maps 13, 173-181.

Lopez Saez, J.A., Texier, P.J., 1998. Paléoenvironment durant le Pléistocene Supérieur en Vaucluse: analyse palynologique des couches inférieures de l'abri de la Combette (Bonnieux, Vaucluse, France). Trab. Prehist. 55, 151.

Macdonald, P., Du, J., 2012. Mixdist: finite mixture distribution models. R package version 0.5-4. https://CRAN.R-project.org/package=mixdist.

Mackay, J.R., Burn, C.R., 2005. A long-term field study (1951-2003) of ventifacts formed by katabatic winds at Paulatuk, western Arctic coast, Canada. Can. J. Earth Sci. 42, 1615-1635.

Magnin, F., 1992. Variations de température en Provence pendant le Pléistocène supérieur (stades isotopiques 2 et 3 ) estimées d'après l'analyse d'associations de gastéropodes terrestres. C. R. Acad. Sci., Ser. II: Mec., Phys., Chim., Sci. Terre Univers 315, 231-237.

Magnin, F., 2014. Middle Pleniglacial to Holocene molluscan assemblages in the Marseille-Aubagne basin (Provence, France). Quaternaire 25, 113-125.

Makó, A., Tóth, G., Weynants, M., Rajkai, K., Hermann, T., Tóth, B., 2017. Pedotransfer functions for converting laser diffraction particle-size data to conventional values:

conversion of particle-size distribution data. Eur. J. Soil Sci. 68, 769-782.

Mandier, P., 1984. Le relief de la moyenne vallée du Rhône au Tertiaire et au Quaternaire. Essai de synthèse paléographique. (Ph.D. Thesis). Université Lyon II, France. 
Marcelin, P., 1926. Contribution à l'étude géographique de la garrigue nîmoise. Études Rhodaniennes 2, 35-180.

Marković, S.B., Stevens, T., Kukla, G.J., Hambach, U., Fitzsimmons, K.E., Gibbard, P., Buggle, B., Zech, M., Guo, Z., Hao, Q., Wu, H., O'Hara Dhand, K., Smalley, I.J., Újvári, G., Sümegi, P., Timar-Gabor, A., Veres, D., Sirocko, F., Vasiljević, D.A., Jary, Z., Svensson, A., Jović, V., Lehmkuhl, F., Kovács, J., Svirčev, Z., 2015. Danube loess stratigraphy - towards a panEuropean loess stratigraphic model. Earth-Sci. Rev. 148, 228-258.

Mason, J.A., Nater, E.A., Zanner, C.W., Bell, J.C., 1999. A new model of topographic effects on the distribution of loess. Geomorphology 28, 223-236.

Mazenot, G., 1956. Recherches sur les faunes malacologiques du loess récent würmien et de divers limons terrestres holocènes dans le sud-est de la France. Bull. Mens. Soc. Linn. Lyon 25, 9-24.

Mazenot, G., 1957. Nouvelles recherches pétrographiques et malacologiques sur le loess et limons de Basse-Provence. Bull. Mens. Soc. Linn. Lyon 26, 271-281.

Mazenot, G., 1965. Existe-t-il à tout prix, en France, une faune de loess? Bull. Assoc. Fr. Étud. Quat. 2, 78-84.

McCauley, J.F., Grolier, M.J., Breed, C.S., 1977. Yardangs of Peru and other desert regions. U.S. Geol. Surv. Interag. Rep. Astrogeology. 81 (Flagstaff, Arizona).

McTainsh, G.H., Nickling, W.G., Lynch, A.W., 1997. Dust deposition and particle size in Mali, West Africa. Catena 29, 307-322.

Médail, F., Diadema, K., 2009. Glacial refugia influence plant diversity patterns in the Mediterranean Basin. J. Biogeogr. 36, 1333-1345.

Meszner, S., Kreutzer, S., Fuchs, M., Faust, D., 2013. Late Pleistocene landscape dynamics in Saxony, Germany: paleoenvironmental reconstruction using loess-paleosol sequences. Quat. Int. 296, 95107.

Middleton, G.V., 1976. Hydraulic interpretation of sand size distributions. J. Geol. 84, 405-426.

Mocochain, L., Clauzon, G., Bigot, J.-Y., 2006. The Ardèche endokarstic responses to the eustatic variations resulting from the Messinian salinity crisis. Bull. Soc. Geol. Fr. 177, 27-36.

Mocochain, L., Audra, P., Clauzon, G., Bellier, O., Bigot, J.-Y., Parize, O., Monteil, P., 2009. The effect of river dynamics induced by the Messinian Salinity Crisis on karst landscape and caves: example of the Lower Ardèche river (mid Rhône valley). Geomorphology 106, 46-61.

Molliex, S., Siame, L.L., Bourlès, D.L., Bellier, O., Braucher, R., Clauzon, G., 2013. Quaternary evolution of a large alluvial fan in a periglacial setting (Crau Plain, SE France) constrained by terrestrial cosmogenic nuclide (10Be). Geomorphology 195, 45-52.

Molodkov, A., Bitinas, A., 2006. Sedimentary record and luminescence chronology of the Lateglacial and Holocene aeolian sediments in Lithuania. Boreas 35, 244-254.

Monjuvent, G., Masse, J., Philip, J., Ballesio, R., Alabouvette, B., Blavoux, B., Granier, J., Dupias, G., 1991. Notice explicative de la carte géologique d'Avignon au 1/50000. BRGM, Orléans.

Mountney, N.P., Russell, A.J., 2004. Sedimentology of cold-climate aeolian sandsheet deposits in the Askja region of northeast Iceland. Sediment. Geol. 166, 223-244.

Muhs, D.R., Benedict, J.B., 2006. Eolian additions to Late Quaternary alpine soils, Indian Peaks Wilderness Area, Colorado Front Range. Arct. Antarct. Alp. Res. 38, 120-130.

Murray, A.S., Wintle, A.G., 2000. Luminescence dating of quartz using an improved singlealiquot regenerative-dose protocol. Radiat. Meas. 32, 57-73. 
Murton, J., 2013. Ice wedges and ice-wedge casts. In: Elias, S.A., Mock, C.J. (Eds.), Encyclopedia of Quaternary Science. Elsevier, Amsterdam.

Novothny, Á., Frechen, M., Horváth, E., Wacha, L., Rolf, C., 2011. Investigating the penultimate and last glacial cycles of the Süttő loess section (Hungary) using luminescence dating, high-resolution grain size, and magnetic susceptibility data. Quat. Int. 234, 75-85.

Nury, D., Roux, R.-M., 1969. Présence de figures de cryoturbation et de cailloutis quaternaires à I'Ouest de Martigues (Bouches-du-Rhône). Bull. Assoc. Fr. Étud. Quat. 6, 139-143.

Obreht, I., Zeeden, C., Schulte, P., Hambach, U., Eckmeier, E., Timar-Gabor, A., Lehmkuhl, F., 2015. Textural and geochemical analyses of the Orlovat loess-paleosol sequence, northern Serbia. PANGAEA https://doi.org/10.1594/PANGAEA.848686 (Supplement to: Obreht, l. et al. (2015): Aeolian dynamics at the Orlovat loess-paleosol sequence, northern Serbia, based on detailed textural and geochemical evidence. Aeolian Res. 18 69-81, https://doi.org/10.1016/j.aeolia.2015.06.004).

O'Hara, S.L., Clarke, M.L., Elatrash, M.S., 2006. Field measurements of desert dust deposition in Libya. Atmos. Environ. 40, 3881-3897.

Onoratini, G., Chareyre, J., Combier, J., Dal-Pra, G., Thinon, M., 1999. In: Sacchi, D. (Ed.), Nouvelles données sur la culture gravettienne en Vivarais. Actes du XXIVème Congrès Préhistorique de France. Les faciès leptolithiques du Nord-Ouest méditerranéen: milieux naturels et culturels. Soc. Préhist. Fr., Carcassonne, pp. 151-163.

Paepe, R., Vanhoorne, R., 1967. The stratigraphy and palaeobotany of the Late Pleistocene in Belgium. Mémoires pour servir à l'explication des Cartes géologiques et minières de la Belgique. 8. Service Géologique de Belgique, Bruxelles, Belgium.

Paton, T.R., 1978. The Formation of Soil Material. George Allen and Unwin Press, London.

Preusser, F., Degering, D., Fuchs, M., Hilgers, A., Kadereit, A., Klasen, N., Krbetschek, M.R., Richter, D., Spencer, J.Q.G., 2008. Luminescence dating: basics, methods and applications. Eiszeit. Gegenw. (Quat. Sci. J.) 57 (1-2), 95-149.

Prognon, F., Lacquement, F., Ricordel-Prognon, C., Quesnel, F., Nehlig, P., Courbouleix, S., Quinquis, J.-P., Martin, P., Rambourg, D., Lebret, P., 2011. Regolith map of France. Quaternaire 22, 357-362.

Puaud, S., Nowak, M., Pont, S., Moncel, M.-H., 2015. Minéraux volcaniques et alpins à l'abri du Maras (Ardèche, France): témoins de vents catabatiques dans la vallée du Rhône au Pléistocène supérieur. C.R. Palevol 14, 331-341.

Pye, K., 1982. Morphological development of coastal dunes in a humid tropical environment, Cape Bedford and Cape Flattery, North Queensland. Geogr. Ann. Ser. Phys. Geogr. 213-227.

Pye, K., 1995. The nature, origin and accumulation of loess. Quat. Sci. Rev. 14, 653-667. Pye, K., Tsoar, H., 2009. Aeolian Sand and Sand Dunes. Springer, Berlin Heidelberg.

Pye, K., Zhou, L.-P., 1989. Late Pleistocene and Holocene aeolian dust deposition in north China and the northwest Pacific Ocean. Palaeogeogr. Palaeoclimatol. Palaeoecol. 73, 11-23.

Qin, X., Cai, B., Liu, T., 2005. Loess record of the aerodynamic environment in the east Asia monsoon area since 60,000 years before present. J. Geophys. Res. Solid Earth 110, B01204.

R Core Team, 2018. R: A Language and Environment for Statistical Computing. Vienna, Austria. URL: https://r-project.org.

Radtke, U., Janotta, A., Hilgers, A., Murray, A.S., 2001. The potential of OSL and TL for dating Lateglacial and Holocene dune sands tested with independent age control of the Laacher See tephra (12,880 a) at the Section Mainz-Gonsenheim. Quat. Sci. Rev. 20, 719-724. 
Ramaswamy, V., Rao, P.S., 2006. Grain size analysis of sediments from the northern Andaman Sea: comparison of laser diffraction and sieve-pipette techniques. J. Coast. Res. 224, 1000-1009.

Raupach, M.R., Woods, N., Dorr, G., Leys, J.F., Cleugh, H.A., 2001. The entrapment of particles by windbreaks. Atmos. Environ. 35, 3373-3383.

Rendell, H.M., Calderon, T., Pérez-González, A., Gallardo, J., Millán, A., Townsend, P.D., 1994. Thermoluminescence and optically stimulated luminescence dating of Spanish dunes. Quat. Sci. Rev. 13, 429-432.

Renssen, H., Kasse, C., Vandenberghe, J., Lorenz, S.J., 2007. Weichselian Late Pleniglacial surface winds over northwest and central Europe: a model-data comparison. J. Quat. Sci. 22, 281-293.

Richter, D., Richter, A., Dornich, K., 2013. Lexsyg - a new system for luminescence research. Geochronometria 40, 220-228.

Römer, W., Lehmkuhl, F., Sirocko, F., 2016. Late Pleistocene aeolian dust provenances and wind direction changes reconstructed by heavy mineral analysis of the sediments of the Dehner dry maar (Eifel, Germany). Glob. Planet. Chang. 147, 25-39.

Ronco, C., Blaizot, F., Durand, E., Frascone, D., Horry, A., Lalaï, D., Morin, E., Bosq, M., 2018. Plateau de Lautagne, Rapport final d'opération. Inrap, SRA Auvergne-Rhône-Alpes, Lyon (in press).

Rousseau, D.-D., Chauvel, C., Sima, A., Hatté, C., Lagroix, F., Antoine, P., Balkanski, Y., Fuchs, M., Mellett, C., Kageyama, M., Ramstein, G., Lang, A., 2014. European glacial dust deposits: geochemical constraints on atmospheric dust cycle modeling: European glacial dust deposits. Geophys. Res. Lett. 41, 7666-7674.

Ruszkiczay-Rüdiger, Z., Braucher, R., Csillag, G., Fodor, L.I., Dunai, T.J., Bada, G., Bourlés, D., Müller, P., 2011. Dating Pleistocene aeolian landforms in Hungary, Central Europe, using in situ produced cosmogenic 10BE. Quat. Geochronol. 6, 515-529.

Saos, T., Djerrab, A., Defleur, A., 2014. Etude stratigraphique, sédimentologique et magnétique des dépôts pléistocène moyen et supérieur de la Baume Moula-Quercy (Soyons, Ardèche).

Quaternaire 25, 237-251.

Sauer, D., Kadereit, A., Kühn, P., Kösel, M., Miller, C.E., Shinonaga, T., Kreutzer, S., Herrmann, L., Fleck, W., Starkovich, B.M., Stahr, K., 2016. The loess-palaeosol sequence of Datthausen, SW Germany: characteristics, chronology, and implications for the use of the Lohne soil as a marker soil. Catena 146, 10-29.

Schatz, A.-K., Zech, M., Buggle, B., Gulyás, S., Hambach, U., Marković, S.B., Sümegi, P., Scholten, T., 2011. The late Quaternary loess record of Tokaj, Hungary: reconstructing palaeoenvironment, vegetation and climate using stable $C$ and $N$ isotopes and biomarkers. Quat. Int. 240, 52-61.

Schlummer, M., Hoffmann, T., Dikau, R., Eickmeier, M., Fischer, P., Gerlach, R., Holzkämper, J., Kalis, A.J., Kretschmer, I., Lauer, F., Maier, A., Meesenburg, J., Meurers-Balke, J., Münch, U., Pätzold, S., Steininger, F., Stobbe, A., Zimmermann, A., 2014. From point to area: upscaling approaches for Late Quaternary archaeological and environmental data. Earth-Sci. Rev. 131, 22-48.

Schoeneich, P., 1998. Corrélation du dernier maximum glaciaire et de la déglaciation alpine avec l'enregistrement isotopique du Groenland. Quaternaire 9, 203-215.

Schulte, P., Lehmkuhl, F., Steininger, F., Loibl, D., Lockot, G., Protze, J., Fischer, P., Stauch, G., 2016. Influence of $\mathrm{HCl}$ pretreatment and organo-mineral complexes on laser diffraction measurement of loess-paleosol-sequences. Catena 137, 392-405. 
Sebe, K., Csillag, G., Ruszkiczay-Rüdiger, Z., Fodor, L., Thamó-Bozsó, E., Müller, P., Braucher, R., 2011. Wind erosion under cold climate: a Pleistocene periglacial mega-yardang system in Central Europe (Western Pannonian Basin, Hungary). Geomorphology 134, 470-482.

Sebe, K., Roetzel, R., Fiebig, M., Lüthgens, C., 2015. Pleistocene wind system in eastern Austria and its impact on landscape evolution. Catena 134, 59-74.

Sima, A., Rousseau, D.-D., Kageyama, M., Ramstein, G., Schulz, M., Balkanski, Y., Antoine, P., Dulac, F., Hatté, C., 2009. Imprint of North-Atlantic abrupt climate changes on western European loess deposits as viewed in a dust emission model. Quat. Sci. Rev. 28, 2851-2866.

Sima, A., Kageyama, M., Rousseau, D.-D., Ramstein, G., Balkanski, Y., Antoine, P., Hatté, C., 2013. Modeling dust emission response to North Atlantic millennial-scale climate variations from the perspective of East European MIS 3 loess deposits. Clim. Past 9, 1385-1402.

Singhvi, A.K., Bluszcz, A., Bateman, M.D., Rao, M.S., 2001. Luminescence dating of loess- palaeosol sequences and coversands: methodological aspects and palaeoclimatic implications. Earth-Sci. Rev. 54, 193-211.

Sitzia, L., Bertran, P., Bahain, J.-J., Bateman, M.D., Hernandez, M., Garon, H., de Lafontaine, G., Mercier, N., Leroyer, C., Queffelec, A., Voinchet, P., 2015. The Quaternary coversands of southwest France. Quat. Sci. Rev. 124, 84-105.

Sitzia, L., Bertran, P., Sima, A., Chery, P., Queffelec, A., Rousseau, D.-D., 2017. Dynamics and sources of last glacial aeolian deposition in southwest France derived from dune patterns, grain-size gradients and geochemistry, and reconstruction of efficient wind directions. Quat. Sci. Rev. 170, 250-268.

Smalley, I.J., 1972. The interaction of great rivers and large deposits of primary loess. Trans. N. Y. Acad. Sci. 34, 534-542.

Smalley, I., O'Hara-Dhand, K., Wint, J., Machalett, B., Jary, Z., Jefferson, I., 2009. Rivers and loess: the significance of long river transportation in the complex event-sequence approach to loess deposit formation. Quat. Int. 198, 7-18.

Smith, B.J., Wright, J.S., Whalley, W.B., 1991. Simulated aeolian abrasion of Pannonian sands and its implications for the origins of Hungarian loess. Earth Surf. Process. Landf. 16, 745-752.

Smith, B.J., Wright, J.S., Whalley, W.B., 2002. Sources of non-glacial, loess-size quartz silt and the origins of "desert loess". Earth-Sci. Rev. 59, 1-26.

Strandberg, G., Brandefelt, J., KjellströM, E., Smith, B., 2011. High-resolution regional simulation of last glacial maximum climate in Europe. Tellus Dyn. Meteorol. Oceanogr. 63, 107-125.

Stuut, J.-B., Smalley, I., O'Hara-Dhand, K., 2009. Aeolian dust in Europe: African sources and European deposits. Quat. Int. 198, 234-245.

Suen, T.-Y., 1934. Le loess de la vallée du Rhône. (Ph.D. Thesis). Faculté des Lettres de I'Université de Lyon, Lyon.

Sun, D., Bloemendal, J., Rea, D.K., Vandenberghe, J., Jiang, F., An, Z., Su, R., 2002. Grain-size distribution function of polymodal sediments in hydraulic and aeolian environments, and numerical partitioning of the sedimentary components. Sediment. Geol. 152, 263-277.

Sun, D., Bloemendal, J., Rea, D.K., An, Z., Vandenberghe, J., Lu, H., Su, R., Liu, T., 2004. Bimodal grainsize distribution of Chinese loess, and its palaeoclimatic implications. Catena 55, 325-340.

Sweeney, M.R., Busacca, A.J., Gaylord, D.R., 2005. Topographic and climatic influences on accelerated loess accumulation since the last glacial maximum in the Palouse, Pacific Northwest, USA. Quat. Res. 63, 261-273. 
Telfer, M.W., Thomas, Z.A., Breman, E., 2012. Sand ramps in the Golden Gate Highlands National Park, South Africa: evidence of periglacial aeolian activity during the last glacial. Palaeogeogr. Palaeoclimatol. Palaeoecol. 313-314, 59-69.

Texier, P.-J., Brugal, J.-P., Desclaux, E., Lemorini, C., Lopez Saez, J.A., Thery, I., Wilson, L., 2003. La Combette (Bonnieux, Vaucluse, France): a Mousterian sequence in the Luberon mountain chain, between the plains of the Durance and Calavon rivers. Preistoria Alpina 39, 77-90.

Thom, A.S., 1975. Momentum, mass and heat exchange of plant communities. In: Monteith, J. (Ed.), Vegetation and the Atmosphere. Academic Press, London, pp. 57-109.

Thomas, P.J., Murray, A.S., Granja, H.M., Jain, M., 2008. Optical dating of Late Quaternary coastal deposits in northwestern Portugal. J. Coast. Res. 2, 134-144.

Tolksdorf, J.F., Kaiser, K., 2012. Holocene aeolian dynamics in the European sand-belt as indicated by geochronological data: Holocene aeolian dynamics in the European sand-belt. Boreas 41, 408-421.

Tóth, G., Jones, A., Montanarella, L., European Commission, Joint Research Centre, Institute for Environment and Sustainability, 2013. LUCAS topsoil survey: methodology, data and results. JRC Technical Reports (Publication of the European Union, Luxembourg).

Tricart, J., 1952. Paléoclimats quaternaires et morphologie climatique dans le Midi méditerranéen. Quat. Sci. J. 2, 172-188.

Tsoar, H., Pye, K., 1987. Dust transport and the question of desert loess formation. Sedimentology 34, 139-153.

Turner, B.R., Makhlouf, I., 2002. Recent colluvial sedimentation in Jordan: fans evolving into sand ramps. Sedimentology 49, 1283-1298.

Tzedakis, P.C., Emerson, B.C., Hewitt, G.M., 2013. Cryptic or mystic? Glacial tree refugia in northern Europe. Trends Ecol. Evol. 28, 696-704.

Újvári, G., Molnár, M., Novothny, Á., Páll-Gergely, B., Kovács, J., Várhegyi, A., 2014. AMS 14C and OSL/IRSL dating of the Dunaszekcső loess sequence (Hungary): chronology for 20 to 150 ka and implications for establishing reliable age-depth models for the last $40 \mathrm{ka}$. Quat. Sci. Rev. 106, 140154.

Újvári, G., Kok, J.F., Varga, G., Kovács, J., 2016. The physics of wind-blown loess: implications for grain size proxy interpretations in Quaternary paleoclimate studies. Earth-Sci. Rev. 154, 247-278.

Vandenberghe, J., 2013. Grain size of fine-grained windblown sediment: a powerful proxy for process identification. Earth-Sci. Rev. 121, 18-30.

Vandenberghe, J., Mücher, H.J., Roebroeks, W., Gemke, D., 1985. Lithostratigraphy and palaeoenvironment of the Pleistocene deposits at Maastricht-Belvédère, southern Limburg, the Netherlands. Analecta 18, 12.

Vandenberghe, J., Huijzer, B.S., Mücher, H., Laan, W., 1998. Short climatic oscillations in a western European loess sequence (Kesselt, Belgium). J. Quat. Sci. 13, 471-485.

Vandenberghe, J., Markovič, S.B., Jovanovič, M., Hambach, U., 2014. Site-specific variability of loess and palaeosols (Ruma, Vojvodina, northern Serbia). Quat. Int. 334-335, 86-93.

Vandenberghe, J., Sun, Y., Wang, X., Abels, H.A., Liu, X., 2018. Grain-size characterization of reworked fine-grained aeolian deposits. Earth-Sci. Rev. 177, 43-52.

Varga, G., 2011. Similarities among the Plio-Pleistocene terrestrial aeolian dust deposits in the world and in Hungary. Quat. Int. 234, 98-108. 
Varga, G., Kovács, J., Újvári, G., 2012. Late Pleistocene variations of the background aeolian dust concentration in the Carpathian Basin: an estimate using decomposition of grain-size distribution curves of loess deposits. Neth. J. Geosci. 91, 159-171.

Varga, G., Cserháti, C., Kovács, J., Szalai, Z., 2016. Saharan dust deposition in the Carpathian Basin and its possible effects on interglacial soil formation. Aeolian Res. 22, 1-12.

Varga, G., Újvári, G., Kovács, J., 2018. Interpretation of sedimentary (sub)populations extracted from grain size distributions of Central European loess-paleosol series. Quat. Int. (in press).

Ventra, D., Dìaz, G.C., de Boer, P.L., 2013. Colluvial sedimentation in a hyperarid setting (Atacama Desert, northern Chile): geomorphic controls and stratigraphic facies variability. Sedimentology 60, 1257-1290.

Ventra, D., Rodríguez-López, J.P., de Boer, P.L., 2017. Sedimentology and preservation of aeolian sediments on steep terrains: incipient sand ramps on the Atacama coast (northern Chile). Geomorphology 285, 162-185.

Ward, A.W., Greeley, R., 1984. Evolution of the yardangs at Rogers Lake, California. Geol. Soc. Am. Bull. 95, 829-837.

Washington, R., Todd, M.C., Lizcano, G., Tegen, I., Flamant, C., Koren, I., Ginoux, P., Engelstaedter, S., Bristow, C.S., Zender, C.S., Goudie, A.S., Warren, A., Prospero, J.M., 2006. Links between topography, wind, deflation, lakes and dust: the case of the Bodélé Depression, Chad. Geophys. Res. Lett. 33, L09401.

Weltje, G.J., 1997. End-member modeling of compositional data: numerical-statistical algorithms for solving the explicit mixing problem. Math. Geol. 29, 503-549.

Weltje, G.J., Prins, M.A., 2007. Genetically meaningful decomposition of grain-size distributions. Sediment. Geol. 202, 409-424.

Wiggs, G.F.S., Bullard, J.E., Garvey, B., Castro, I., 2002. Interactions between airflow and valley topography with implications for aeolian sediment transport. Phys. Geogr. 23, 366-380.

Wolfe, S.A., Nickling, W.G., 1993. The protective role of sparse vegetation in wind erosion. Prog. Phys. Geogr. 17, 50-68.

Wolfe, S.A., Nickling, W.G., 1996. Shear stress partitioning in sparsely vegetated desert canopies. Earth Surf. Process. Landf. 21, 607-619.

Wright, J., 2001. Making loess-sized quartz silt: data from laboratory simulations and implications for sediment transport pathways and the formation of 'desert' loess deposits associated with the Sahara. Quat. Int. 76, 7-19.

Xu, L., Mu, G., Ren, X., Wan, D., He, J., Lin, Y., 2016. Oasis microclimate effect on the dust deposition in Cele Oasis at southern Tarim Basin, China. Arab. J. Geosci. 9, 1-7.

Yaalon, D.H., Ganor, E., 1973. The influence of the dust on soils during the Quaternary. Soil Sci. 116, 146.

Youssef, F., Visser, S.M., Karssenberg, D., Erpul, G., Cornelis, W.M., Gabriels, D., Poortinga, A., 2012. The effect of vegetation patterns on wind-blown mass transport at the regional scale: a wind tunnel experiment. Geomorphology 159-160, 178-188.

Zech, R., Zech, M., Marković, S., Hambach, U., Huang, Y., 2013. Humid glacials, arid interglacials? Critical thoughts on pedogenesis and paleoclimate based on multi-proxy analyses of the loesspaleosol sequence Crvenka, Northern Serbia. Palaeogeogr. Palaeoclimatol. Palaeoecol. 387, 165175. 
Zeeberg, J., 1998. The European sand belt in eastern Europe-and comparison of Late Glacial dune orientation with GCM simulation results. Boreas 27, 127-139.

Zeeden, C., Lehmkuhl, F., Chu, W., 2017a. Granulometry of archaeological site Sena I (southern Slovakia). PANGAEA https://doi.org/10.1594/PANGAEA.873323 Supplement to: Chu, W., Lengyel, G., Zeeden, C., Péntek, A., Kaminská, L., Mester, Z. (2017): Early Upper Paleolithic surface collections from loess-like sediments in the northern Carpathian Basin. Quat. Int., https://doi.org/10.1016/j.quaint.2017.05.017).

Zeeden, C., Lehmkuhl, F., Chu, W., 2017b. Granulometry of archaeological site SzécsénkeBerecz-oldal 3, transect 2 (northern Hungary). PANGAEA https://doi.org/10.1594/ PANGAEA.873319 (Supplement to: Chu, W., Lengyel, G., Zeeden, C., Péntek, A., Kaminská, L., Mester, Z. (2017): Early Upper Paleolithic surface collections from loess-like sediments in the northern Carpathian Basin Quat. Int., https://doi.org/ 10.1016/j.quaint.2017.05.017).

Zens, J., Schulte, P., Klasen, N., Krauß, L., Pirson, S., Burow, C., Brill, D., Eckmeier, E., Kels, H., Zeeden, C., Spagna, P., Lehmkuhl, F., 2018. OSL chronologies of paleoenvironmental dynamics recorded by loess-paleosol sequences from Europe: case studies from the Rhine-Meuse area and the Neckar Basin. Palaeogeogr. Palaeoclimatol. Palaeoecol. (in press).

Ziegler, P.A., Dèzes, P., 2007. Cenozoic uplift of Variscan Massifs in the Alpine foreland: timing and controlling mechanisms. Glob. Planet. Chang. 58, 237-269.

Zieliński, P., Sokołowski, R.J., Woronko, B., Jankowski, M., Fedorowicz, S., Zaleski, I., Molodkov, A., Weckwerth, P., 2015. The depositional conditions of the fluvioaeolian succession during the last climate minimum based on the examples from Poland and NW Ukraine. Quat. Int. 386, 30-41. 